\title{
FLORISTIC DIVERSITY AND NOTES ON THE VEGETATION OF Bahía Magdalena area, Baja California Sur, México
}

\author{
José Luis León-de la LuZ', Alfonso Medel-Narváez and Raymundo Domínguez-Cadena \\ Herbario HCIB, Centro de Investigaciones Biológicas del Noroeste, La Paz, Baja California México \\ Corresponding autor: jlleon04@cibnor.mx
}

\begin{abstract}
The Bahía Magdalena region of the Baja California Peninsula is floristically part of the southern Sonoran Desert. It has several particular geographical features, of particular importance the influence of the cold California Current. We present a floristic study of the higher plants on a land area covering $5,158 \mathrm{~km}^{2}$. The flora has 506 taxa: five ferns, two gymnosperms, $438 \mathrm{magnoli}-$ opsida (dicotyledons), and 60 liliopsida (monocotyledons), representing 85 families and 280 genera. The plant families with major species diversity are: Asteraceae, Poaceae, Euphorbiaceae, and Fabaceae. The flora was categorized into nine life forms: perennial herbs (127) and annuals (143) represent $54 \%$ of all species. The flora occupies eight plant communities, which are described; the most extensive community is the fog sarcocaulescent scrubland. From a biological perspective, Margarita and Magdalena islands are important areas to preserve as core zones in a future management plan because they support 19 endemic species. Mangroves and sea grass marshes are important areas serving as nursery habitats for marine fauna. Mexican environmental authorities are considering establishing a reserve to protect biodiversity in the region.
\end{abstract}

Key words: Pacific coastal islands, plant diversity, sarcocaulescent scrubs, Sonoran Desert.

Resumen: La región de Bahía Magdalena de la Península de Baja California ha sido considerada florísticamente parte del sur del Desierto Sonorense. Presenta diversos rasgos geográficos importantes, tales como la influencia de la fría corriente de California. Este trabajo presenta un estudio florístico de los vegetales superiores que abarca $5,158 \mathrm{~km}^{2}$ de territorio. La flora consiste de 506 taxa de plantas vasculares: cinco de helechos, dos de gimnoespermas, 438 magnoliopsida (dicotiledóneas) y 60 liliopsida (monocotiledóneas), agrupadas en 85 familias y 280 géneros. Las familias con mayor diversidad de especies son: Asteraceae, Poaceae, Euphorbiaceae y Fabaceae. La flora resultante fue categorizada en nueve formas de crecimiento: Las herbáceas perennes (127) y las anuales (143) representan el $54 \%$ de todas las especies. La flora ocupa ocho comunidades vegetales; la más extendida es el matorral sarcocaule de neblina. Desde una perspectiva biológica, las islas Margarita y Magdalena son las áreas más importantes para considerarlas dentro de una zona núcleo en un futuro plan de manejo, porque estas incluyen a 19 especies endémicas. Los manglares y los pastizales marinos son áreas importantes para la crianza de la vida marina. Las autoridades ambientales mexicanas consideran actualmente su inclusión como área de protección a su biodiversidad.

Palabras clave: desierto Sonorense, diversidad de plantas, islas del Pacífico, matorral sarcocaule.

B iodiversity is commonly understood as the variety of life in all its forms, levels, and combinations; more specifically, it is the degree of variation of all life forms and their ecological processes within a given ecosystem (Wilson, 1988). Biodiversity encompasses many levels of life organization such as species, ecosystems, and genetics, but the easiest category to visualize, and that is most commonly used, is the number of species in a particular region.

Biological inventories have traditionally been considered the most extensive means of documenting species biodiversity. Diversity of flowering plants of the Baja California
Peninsula was cataloged by Wiggins (1980), with 2,958 taxa (species and varieties/subspecies) with $23 \%$ being endemic. Rebman and Roberts (2013) state than that number could reach 4,000 taxa when field work of the entire peninsula is completed and precise taxonomic work performed.

In the arid and semiarid regions of northern Mexico, plants have evolved into a moderately rich and distinctive flora with specialized growth forms and a high rate of endemism (Rzedowski, 1973). The Baja California Peninsula has a long history of field studies, documentation, and interpretation of land flora. Several floristic treatments have been 
published for all of the territory or parts, including some taxonomic revisions (Shreve and Wiggins, 1964; Gentry, 1978; Wiggins, 1980; Gould and Moran, 1981; Daniel, 1997). Studies of plant diversity of the Baja California Peninsula have covered most of the region, but there are some regions without detailed floristic work; the most intensive collections were performed in the northern and southern sectors (Arriaga et al., 2005). An example of an area that has not received as much attention is the Bahía Magdalena region. This land has remained under low pressure from the local population, but the marine environment has been severely exploited in the last two decades (Funes-Rodríguez et al., 2007). Consequently, some civil organizations have shown interest and have proposed legal protection of the area to government environmental authorities (Danemann, 2010).

The objective of present research was to assess the diversity and distribution of higher plants found in the vicinity of Bahía Magdalena to propose short term management schemes for providing continued biodiversity, conservation, and legal protection of the area.

\section{Methods}

Study area. Magdalena Bay area, including the islands of Margarita, Magdalena, and Creciente are an ample surface considered by the Comisión Nacional para el Conocimiento y uso de la Biodiversidad (CONABIO) as both Mexican terrestrial and marine regions important for conservation, known as the Planicies de Bahía Magdalena (terrestrial) and Bahía Magdalena (marine), with 5,648 $\mathrm{km}^{2}$ and 17,578 $\mathrm{km}^{2}$ respectively (Arriaga et al., 2000a, b; Bizarro, 2008). Shreve and Wiggins (1964) and Wiggins (1960) recognized this area as the Magdalena Plains subdivision of the Sonoran Desert.

Figure 1 outlines our study area, which is almost the same than the area designated by CONABIO as the Planicies de Bahía Magdalena. The study area is a polygon that comprises only terrestrial land from Highway 1 to the $\mathrm{Pa}$ cific coast and bounded on the north at $25^{\circ} 52^{\prime} \mathrm{N}$ and on the south at $24^{\circ} 22^{\prime} \mathrm{N}$. This area includes $5,018 \mathrm{~km}^{2}$ of country, from which about $750 \mathrm{~km}^{2}$ is devoted to farming (Valle de Santo Domingo), which is excluded from this study. Around $1,200 \mathrm{~km}^{2}$ are occupied by lagoons, which includes mangrove stands and prairies of marine phanerogams. Most of the study area is within the Municipality of Comondú and only a bit of the southernmost sector is in the Municipality of La Paz, both are within the jurisdiction of the State of Baja California Sur.

Climate. According to García (1973) most of the area is hot and very dry (BWh in Köppen climate classification), with at least $80 \%$ of the rainfall occurring in summer. The few weather stations in the area record annual averages as follows: Poza Grande 64 mm, Puerto Magdalena 83 mm, Puer-

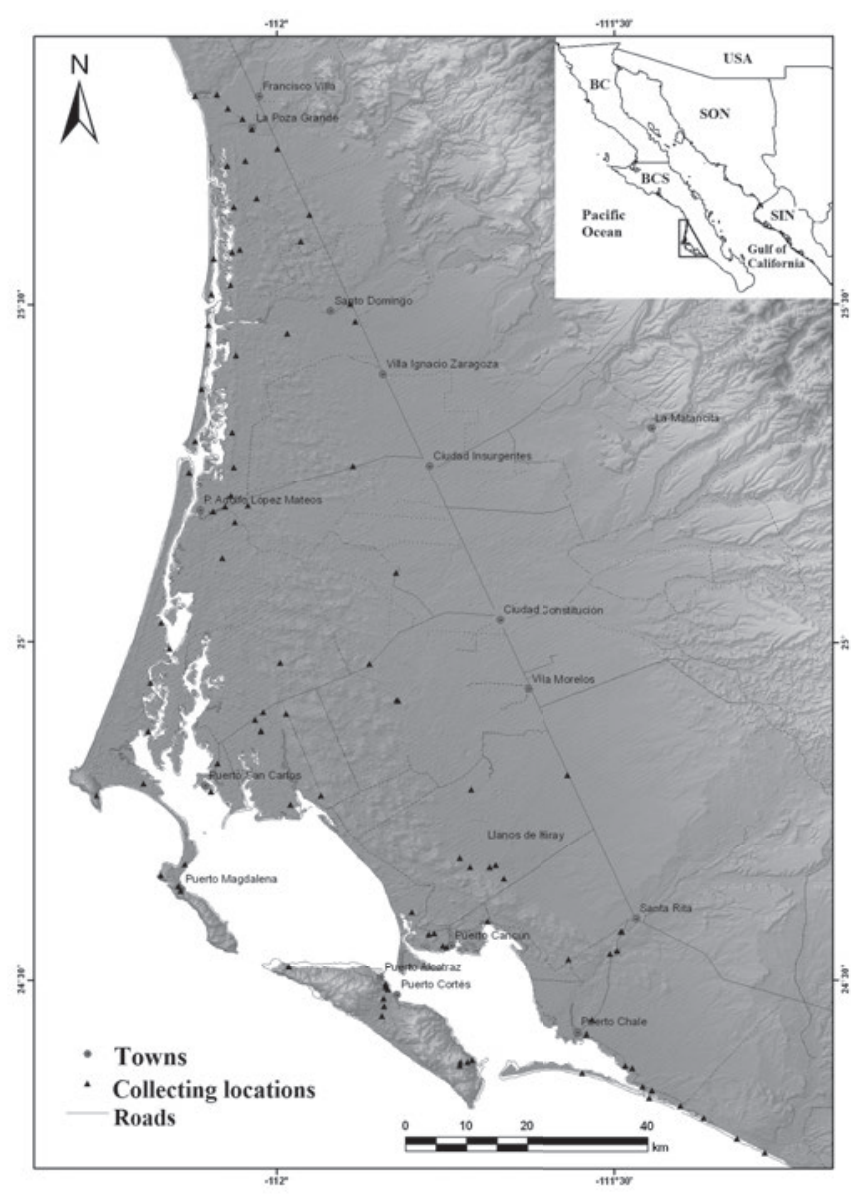

Figure 1. Polygon of the study area and location of the 116 collecting sites. Highway 1 is the main limit in the peninsular land.

to Adolfo López Mateos $89 \mathrm{~mm}$, Puerto San Carlos $98 \mathrm{~mm}$, and Santo Domingo $104 \mathrm{~mm}$; but eventually, when strong hurricanes impact the area as one did in 2009, up to 200 $\mathrm{mm}$ is recorded in hours. Mean annual average temperature in those same stations is by $21{ }^{\circ} \mathrm{C}$, with January having a mean temperature of $17^{\circ} \mathrm{C}$ and August and September have a mean of $28^{\circ} \mathrm{C}$. Tropical storms that originate in the tropical eastern Pacific are the main source of moisture. From 2001 through 2013, four hurricanes and five tropical storms directly affected the area (Unisys Co., 2013). In addition to the rain events, an important physical factor that characterizes this region is the low and thin morning advection fog, resulting from westerly moist Pacific air, moving across the cold California Current. The wind drives saturated air inland (up to $25 \mathrm{~km}$ ) most of the year; typically fog is present from the first hours to 9-10 in the morning, being heaviest from January to May.

Vegetation and soils. Vegetation on most part of the peninsula, including the study area, is designated as sarcocaulescent scrubland (matorral sarcocaule) according to the official Mexican chart of vegetation (DEGETENAL, 1981). This is 
a variation of the well-recognized desertic or xerophyllous scrubland (matorral xerófilo), a generic name for the vegetation of arid and semi-arid regions in Mexico. Rzedowski $(1978,1979)$ proposes that such scrubland is the expression of the transition between the southern dry-tropical vegetation and the northerly desertic in the Baja California peninsula, functionally equivalent in mainland Mexico to the thorn scrub, thorn forest, or Sinaloan deciduous forest (Brown, 1994) that characterize the same transition along the coastal plains of northwestern Mexico in southern Sonora.

A coastal strip of land on the Pacific side of the peninsula, from $26^{\circ} 25^{\prime} \mathrm{N}$ to $24^{\circ} 18^{\prime} \mathrm{N}$, is named in the Mexican official chart (DEGETENAL, 1981) as fog sarco-crassicaulescent scrubland (matorral sarco-crasicaule de neblina), which is the most widespread vegetation in the study area.

Soils are classified into four major types:

(1) Isla Magdalena and Isla Margarita have hills up to 550 $\mathrm{m}$ composed of Triassic-Jurassic rocks that are among the oldest of the peninsula, and are one of the 20 areas in Mexico with serpentine rocks (Ortíz-Hernández et al., 2006). Soils that develop from the high content of magnesium are extremely limiting to the variety of plants that can tolerate these conditions (Brady et al., 2005).

(2) Parts of the islands (Margarita, Magdalena, and Creciente), as well parts of the coast, are sandy, forming active or stabilized dune fields of Holocene age (Murillo et al., 1994); the fog sarco-crassicaulescent scrubland typically occupies stabilized dunes located as far as $25 \mathrm{~km}$ inland, up to $50 \mathrm{~m}$ above sea level.

(3) Gley (waterlogged) clay soils are of Pleistocene and Holocene age; mostly associated with mangroves (manglares) and salt flats (salitrales) along the shores of the lagoons (González-Zamorano et al., 2011).

(4) Flat areas are composed of alluvial soils derived from run-off carrying fine sands and silts, these occupy the lowest elevations of endorheic watersheds. They are closed basins that retain runoff for weeks to months, and when dry, leave silty deposits at the surface.

Botanical history. The first botanical expedition in this and surrounding areas occurred in 1837, when the English ship HMS Sulphur sailed up the west coast of the North American continent and elsewhere (Bentham, 1844). During the voyage, botanists collected a large number of plants surrounding Cabo San Lucas and Bahía Magdalena. This expedition yielded more than 100 new species for the peninsular and Mexican flora, which nowadays carries the species authority Benth. (George Bentham). Between 1889 and 1902, the Californian botanist Townshend Stith Brandegee made several trips to the southern Baja California Peninsula; the first trip in January and February 1889 included exploration in the Bahía Magdalena area (Brandegee, 1889), where he collected 158 taxa, including 12 new species, some of them endemic to Margarita and Magdalena islands. Several expeditions to these islands during the 20th century were leaded by Californian botanists (Shreve and Wiggins, 1964; Wiggins, 1980), but no novel species were reported except the description of a new species collected by Howard Scott Gentry in 1939, Tuctoria fragilis (Sw.) Reeder in the Hyrai plains.

Logistic. In September 2009, with support from CONABIO, we began fieldwork in this area just after the landfall of Hurricane Jimena in this area (Category 4 on the Saffir-Simpson scale). Within the boundaries of the Bahía Magdalena area (Figure 1), about 190 to $210 \mathrm{~km}$ of dirt roads provide access by two- and four-wheel drive vehicles. The islands were reached by small motor boats (pangas). Specimens were collected, preserved, and archived by traditional procedures (Lot and Chiang, 1986).

All collected specimens are in the CIBNOR herbarium in La Paz, BCS (HCIB). Some duplicates were exchanged with the San Diego Natural History Museum (SD). The basic references for identification and nomenclature were Wiggins (1980) and Shreve and Wiggins (1964). Some additional references were consulted (Bravo-Hollis, 1978; Bravo-Hollis and Sánchez-Mejorada, 1991a, b; Gentry, 1978; Gould and Moran, 1981; Hickman et al., 1993; and Turner et al., 1995). Subsequently a checklist was prepared consulting Spears (2006) and Tropicos webpage (2013) of the Missouri Botanical Garden for updating of nomenclature which basically follows APG III (Angiosperm Phylogeny Group) classification.

\section{Results}

The flora. Over 38 months we visited 116 collection sites, which are shown in Figure 1. A database of all collections from the study area was assembled that includes 2,294 specimens, which can be consulted online at CONABIO webpage by request (http://www.conabio.gob.mx/institucion/cgi-bin/datos.cgi?Letras $=H J \&$ Numero $=2$ ). Of these, 1,835 are the contribution from our field collections, 158 more are reported by Brandegee (1889), and the remaining 301 are included in the BajaFlora database (www.bajaflora. org), which represents a consortium of seven herbariums that collected and archived plant information from the Baja California Peninsula through most of the 20th century, such database is operated by the San Diego Natural History Museum (SDNHM). Table 1a synthesizes the main taxonomic groups of the 506 taxa of vascular plants in the study area. The attached Appendix 1 shows the floristic checklist, which contains five taxa (species and infraspecies) of ferns, two of gymnosperms, and 498 of Magnoliophyta (angiosperms) consisting of 438 magnoliopsida (dicotyledons) and 60 liliopsida (monocotyledons). The flora is represented in 86 families and 280 genera.

Almost $50 \%$ of the flora occurs in 13 families, the best- 
Table 1. (A) Floristic diversity composition of the major taxonomic groups of the 506 vascular plant taxa (species and infraspecies) compiled for Bahía Magdalena flora. (B) Distribution of life forms for Bahía Magdalena flora. Tr (trees), Sh (shrubs), Ph (perennial herbs), An (annual herbs), Hf (hydrophytes), Pa (parasites), Sc (succulents), Vi (vines), Ep (epiphytes), and $\operatorname{Pr}$ (prostrate plants).

A

\begin{tabular}{lcccc}
\hline & Families & Genera & Species & Infraspecies \\
\hline Ferns & 2 & 3 & 4 & 1 \\
Gymnosperms & 1 & 1 & 2 & 0 \\
Liliopsida & 9 & 39 & 57 & 3 \\
Magnoliopsida & 74 & 237 & 399 & 40 \\
TOTAL & 86 & 280 & 462 & 44 \\
\hline
\end{tabular}

\begin{tabular}{llllllllll} 
B & & & & & & & & & \\
\hline $\operatorname{Tr}$ & Sh & Ph & An & Hf & Pa & Sc & Vi & Ep & Pr \\
6 & 91 & 127 & 143 & 27 & 5 & 53 & 21 & 1 & 32
\end{tabular}

represented are Asteraceae (68 taxa), Poaceae (42), Euphorbiaceae (39), and Fabaceae s.l. (35). Forty-three families are represented by a single species. Euphorbia is the most diverse genus (23 taxa), others are Atriplex (11), Ambrosia (10), Lycium (9), Perityle (7), Cryptantha (6), Sphaeralcea (6), Physalis (6), Bahiopsis (5), Boerhavia (5), Encelia (5), Ipomoea (5), Leptochloa (5), and Suaeda (5).
As in other dry tropical areas in Mexico, families Asteraceae, Poaceae, Fabaceae s.l., and Euphorbiaceae predominate in the floristic list; as in southwestern Sonora, bordering the Sonoran Desert (Martin et al., 1998; Van Devender, 2000), and the southern part of the peninsula (León de la Luz et al., 2008).

The resulting flora was categorized as nine life forms (Table 1b) whose classification is compatible with the proposals of Shreve (1951), Crosswhite and Crosswhite (1984), and Medina (1999) for the Sonoran Desert and dry tropical floras. Single-stemmed herbaceous plants, perennials (127) and annuals (143), represent $53 \%$ of all species. Trees are poorly represented (6), but there are significant shrubby forms (91). Hydrophytes (27) include aquatic and marine plants and those growing in moist soils, mostly in mangroves, vernal pools, springs, and at the only oasis in the area (el médano). Succulents (53) are a complex group that includes rossete-stemmed and leaf succulents that are members of the Agavaceae, Aizoaceae, Bromeliaceae, Cactaceae, Crassulaceae, and Portulacaceae families; also some semi-succulents forms in the Anacardiaceae, Burseraceae, and Capparaceae families were here included. Parasites (5) include dodder (Cuscuta) and mistletoe (Psittacanthus and Phoradendron). Vines (21) belong to Asclepiadaceae, Con-

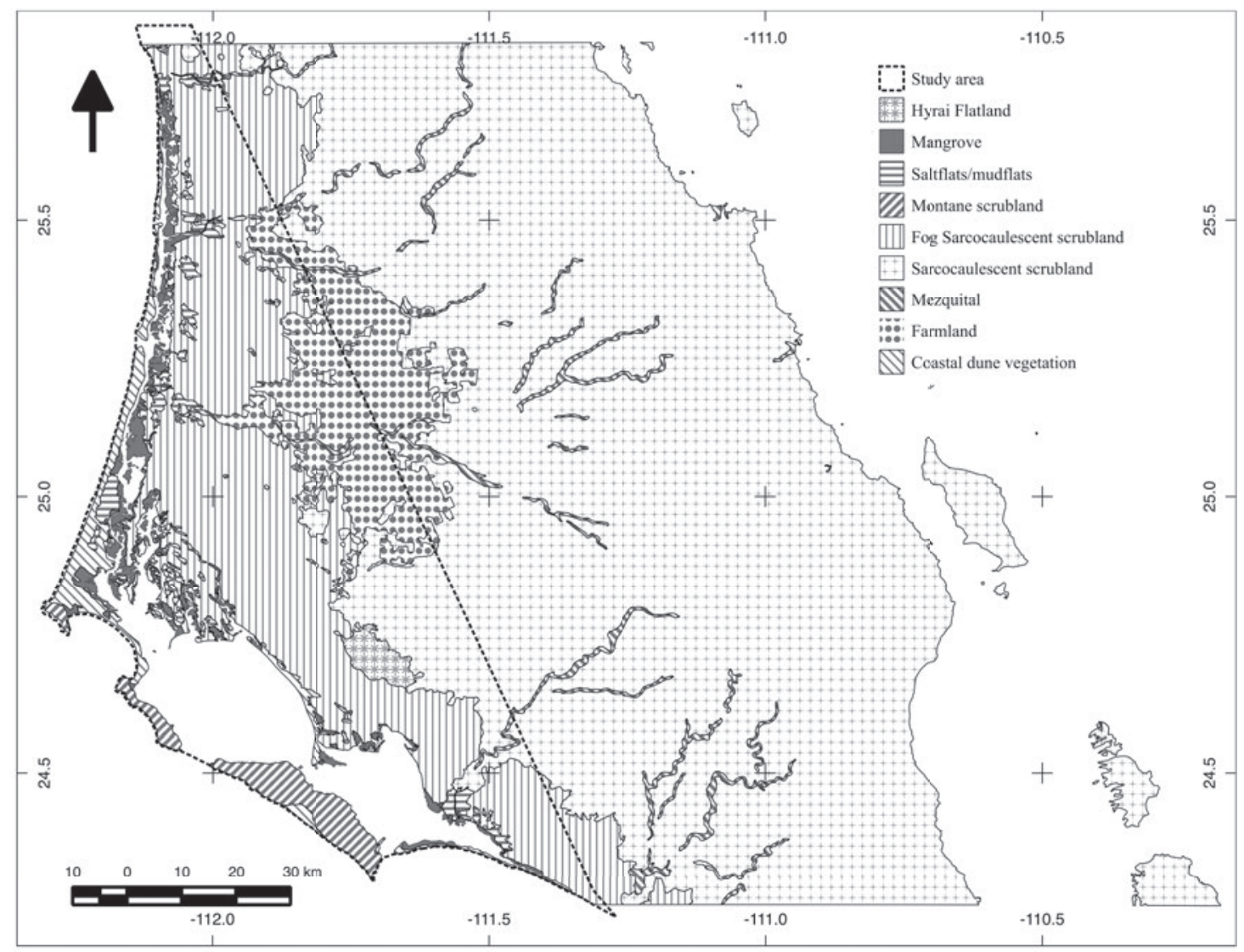

Figure 2. Spatial distribution of the vegetation or plant associations within the study site. Modified from the INEGI image (CONABIO, 2002). 
volvulaceae, Cucurbitaceae, Passifloraceae, Sapindaceae, and other families. Prostrate or low ground-cover plants (32) include annual or perennial herbs with decumbent and procumbent growth and those that form mats, these typically inhabit sandy soils. Some species can be present in two or three categories, but the most prominent character was considered in this classification.

In the flora checklist, families in each major group are arranged in alphabetical order according modern classification (Spears, 2006), and then by genus, species, and infraspecies. Well known non-native and invasive taxa are indicated with an asterisk (*). After the author name, we include, in some cases, inside square brackets, alternative names for these taxa, especially when there are changes in nomenclature from Wiggins (1980), our primary floristic reference, these names were consulted in Tropicos (2011) webpage. For all entries, we include, after the scientific name and author, a two-letter code for the life forms listed in Table 1b. Finally, a common name for the taxon, if applied in the area, is included.

Plant communities. Figure 2 shows the spatial distribution of the vegetation types or plant associations, which were modified from the INEGI image (CONABIO, 2002). The sarcocaulescent scrubland is the most extensive vegetation type of the peninsula; in the study area, it occupies the innermost inland surface between $50 \mathrm{~m}$ and $70 \mathrm{~m}$ above sea level. Subtle variants of this type, considered in the older and recent INEGI charts, are the crassi-caulescent, sarcocrassi-caulescent, and desert microphyllous scrublands. These designations depend on the physiognomically dominant plants (cacti, semi-succulents, and shrubby legumes, respectively). Such scrubland covers almost $700 \mathrm{~km}^{2}$ within the study area, and the physiognomy of this vegetation includes stemmed succulent forms, such as Pachycereus pringlei, Lophocereus schottii var. schottii, Stenocereus thurberi var. thurberi, S. gummosus, Cylindropuntia cholla, and semi-succulent plants, such as Jatropha cinerea, J. cuneata, Bursera microphylla, Fouquieria diguetii; shrubby plants with microphylous leaves, such as Atriplex linearis, Ambrosia magdalenae, Larrea tridentata, and leguminous shrubs and trees, such as Acacia constricta, Mimosa purpurascens, Parkinsonia florida, P. praecox, and Prosopis palmeri.

A special type of sarcocaulescent scrubland covers a strip of land up to 15 to $25 \mathrm{~km}$ wide parallel to the coast of Bahía Magdalena, which contains sandy soils derived from marine sediment, an ancient beach or paleodune gradually rises inland above sea level to reach up to $50 \mathrm{~m}$. The most common are Fouquieria diguetii, Jatropha cinerea, J. cuneata, Pachycereus pringlei, and Stenocereus gummosus. This vegetation is the most extensive in the study area, occupying $3,300 \mathrm{~km}^{2}$. The fog supports a rich lichen flora dominated by Rocella decipiens Darb., $R$. gracilis Bory, $R$. peruensis (Krempelh.) Darb., R. portentosa (Gay) Darb., Lecanora caesiorubella Ach., Niebla cephalota (Tuck.) Rundell and Bowler, and N. ceruchis Rundell and Bowler. These grow on shrub foliage (Nash III et al., 2002); the bromeliad Tillandsia recurvata is also common.

A plant association called locally mezquital is dominated by the mezquite Prosopis articulata, which grows along the margins of arroyos or drainage systems on the western side of the Sierra de La Giganta. Such conditions are more common on alluvial plains toward the Pacific coast. In this relatively small plant association, which occupies no more than $35 \mathrm{~km}^{2}$, local farmers use the mezquite wood for making charcoal. The mezquital follows arroyos on the vegetation maps, but they are not continuous; the density of trees is variable, sometimes dense, but sparse in other areas. This community is ecologically important as evergreen patches of vegetation on the landscape because the indigenous animals intensively use the trees for shelter, nesting sites, and feeding. Other species in this association are Vallesia glabra, Ambrosia ambrosioides, and Acacia farnesiana, although this last seems to be introduced and dispersed by cattle that concentrate in suitable places for forage and shade. Along these same drainage ways, there are occasional small riparian wetlands or oasis with standing water, but within the study area, only one oasis was found (el médano), which is characterized by the Bonpland willow Salix bonplandiana.

There are sparse and small areas that are irregularly and seasonally inundated. The largest in surface area is called llano de Hiray, covering some $65 \mathrm{~km}^{2}$. Adding all similar formations, this habitat could cover some $100 \mathrm{~km}^{2}$. The lowest areas of the llano de Hiray are about $2 \mathrm{~m}$ below sea level. After heavy rains, these low-lying areas remain flooded for weeks, or months, because there is no external drainage to the sea. When flooded, the water percolates slowly or evaporates; thus, a succession of hydrophytes occupies the flats, species that are present are adapted to specific depths of water, season, and water-holding capacity of the soil. Tuctoria fragilis is a locally endemic grass in this wetland that covers the landscape, appearing when the soil reaches moderately high water content. Other hydrophytes found in ponds or seasonal arroyos include Ammannia coccinea, Bergia texana, Eleocharis geniculata, Lythrum spp., Marsilea fournieri, Mecardonia vandellioides, Petunia parviflora, and Stemodia durantifolia. During dry seasons, some semi-halophytic species are common, including Heliotropium curassavicum and Argemone gracilenta, which are particularly abundant sometimes.

The mangrove surrounding Bahía Magdalena is the most extensive on the peninsula, covering an area of $236 \mathrm{~km}^{2}$ (González-Zamorano et al., 2011). Rizhophora mangle and Laguncularia racemosa are common near drainage channels; Avicennia germinans occurs inland, where flooding occurs during the highest tides a few times a year. Associated with the mangroves, particularly behinds stands of $A$. germinans are the saltwort Batis maritima and shoregrass 
Monanthochloe littoralis. The mangrove stands have a dynamic link with tidal conditions $( \pm 0.85 \mathrm{~m})$, usually through extensive tidal channels that flood the mangrove. Blocked channels lead to the death of ample surfaces of mangrove, starting in the shallowest depths. Fresh water supply is irregular, which usually occurs when extraordinary rains discharges through the few arroyos that reaches the coast. There is no evidence of undersea discharge of freshwater from the land.

Slightly higher than the mangrove stands, the soils are usually wet but can quickly dry out. These are clayey soils that are rich in organic matter, but highly alkaline and saline. They are limited to a few vascular plants. The vegetation is dominated by members of the Chenopodiaceae, commonly referred to as salitrales (saltflats or mudflats) that occupy $202 \mathrm{~km}^{2}$ (González-Zamorano et al., 2011). These areas flood during irregular high tides that occur from July through December or after heavy summer rainstorms. Succulent and halophytic plants are characteristic. The most common plant is Allenrolfea occidentalis, with Arthrocnemum subterminale, Sarcocornia pacifica, and Salicornia bigelovii. Bordering the saltflats are a characteristic plant association dominated by Lycium (L. andersonii, L. berlandieri, L. brevipes, L. fremontii, and L. megacarpum), Castela peninsularis, and species of Suaeda.

On the islands, two vegetation types are well established: one we designated as montane scrubland (matorral montano). This appears only on rocky mountainous areas on the islands (two on Magdalena and one on Margarita), covering an area of $250 \mathrm{~km}^{2}$. This montane scrubland is sparse and low vegetation that covers the slopes of the hills of both islands. After heavy rains, the canopy is estimated to have 40 to $60 \%$ coverage. Some of the most common plants are Ambrosia magdalenae, Bajacalia tridentata, Euphorbia misera, Fouquieria diguetii, Jacquemontia abutiloides, Jatropha cuneata, J. canescens, Lippia palmeri, Marina parryi, Pachycormus discolor, Porophyllum gracile, Stenocereus gummosus, and Simmondsia chinensis. Dominant island endemics include Bahiopsis subincisa, Cochemiea halei, Echinocereus barthelowanus, Gongylocarpus fruticulosus, and Opuntia pycnantha. Subordinate plants include Bebbia juncea, Bursera hindsiana, Castela peninsularis, Euphorbia lomelii, Gossypium harknessii, Ipomoea jicama, and Pachycereus pringlei.

The coastal dune vegetation (vegetación de dunas costeras) includes beaches, sand bars, and extensive dune fields that occupy about $230 \mathrm{~km}^{2}$, most on Isla Creciente and Isla Magdalena (Aguirre Muñoz et al., 2010). On the peninsula el médano amarillo is the best representation of coastal dunes. Abronia maritima, Sporobolus virginicus, and Sesuvium portulacastrum are the pioneer plants, with rhizomatous and prostrate life forms on the new or active dunes, where sand is transported mainly by wind and secondly by high tides; this result was also annotated by Johnson (1977).
Stable dunes are commonly covered with Aristida californica, Astragalus magdalenae, Funastrum arenarium, $F$. peninsulare, Lotus bryantii, Palafoxia arenaria, P. linearis, and Psorothamnus emoryi var. arenarius.

Species such as Encelia ventorum and Isocoma menziesii are relatively common in the northern and central coast of the peninsula, but are still found in the dune fields in our area. A tropical species, Scaevola plumieri was found healthy on stable dunes on Isla Magdalena, reaching its northern geographic limit. Some shrubby species, typical in the Cape Region desert scrubland, are present here, especially Ebenopsis confinis, where it forms thick cover between dune crests. Widespread annual life forms include Amaranthus palmeri, Cenchrus palmeri, and Phaseolus filiformis which are abundant after summer rains; Boeberastrum anthemidifolium, Camissonia sceptrostigma, Perityle spp., and Sphaeralcea spp. appear after limited winter rains.

Marine vegetation consists of a few species; the surf grasses Phyllospadix scouleri and P. torreyi inhabit the breaker zone on the Pacific seashore of Isla Magdalena and Isla Margarita. These species grow in large clumps or beds exposed during low tide and submerged at high tide. They

Table 2. Endemic vascular plant taxa in the Bahía Magdalena study area. 1 (island endemics), 2 (peninsular endemics), 3 (islands and peninsula).

\begin{tabular}{|c|c|}
\hline $\begin{array}{l}\text { Agavaceae } \\
\text { Agave margaritae }\end{array}$ & 1 \\
\hline $\begin{array}{l}\text { Asclepiadaceae } \\
\text { Asclepias masonii }\end{array}$ & 1 \\
\hline $\begin{array}{l}\text { Asteraceae } \\
\text { Bahiopsis subincisa } \\
\text { Encelia halimifolia }\end{array}$ & $\begin{array}{l}1 \\
3\end{array}$ \\
\hline $\begin{array}{l}\text { Brassicaceae } \\
\text { Dryopetalum purpureum }\end{array}$ & 1 \\
\hline $\begin{array}{l}\text { Cactaceae } \\
\text { Cochemia halei } \\
\text { Cylindropuntia santa-maria } \\
\text { Echinocereus barthelowanus } \\
\text { Ferocactus townsendianus var. santa-maria } \\
\text { Opuntia pycnantha } \\
\text { Stenocereus eruca }\end{array}$ & $\begin{array}{l}1 \\
1 \\
1 \\
1 \\
3 \\
2\end{array}$ \\
\hline $\begin{array}{l}\text { Fabaceae } \\
\text { Dalea brandegeei } \\
\text { Mimosa margaritae }\end{array}$ & $\begin{array}{l}3 \\
1\end{array}$ \\
\hline $\begin{array}{l}\text { Malvaceae } \\
\text { Sphaeralcea coulteri var. margaritae }\end{array}$ & 1 \\
\hline $\begin{array}{l}\text { Onagraceae } \\
\text { Gongylocarpus fruticulosus subsp. fruticulosus } \\
\text { Gongylocarpus fruticulosus subsp. glaber }\end{array}$ & $\begin{array}{l}1 \\
1\end{array}$ \\
\hline $\begin{array}{l}\text { Poaceae } \\
\text { Muhlenbergia brandegei } \\
\text { Tuctoria fragilis }\end{array}$ & $\begin{array}{l}1 \\
2\end{array}$ \\
\hline $\begin{array}{l}\text { Pteridaceae } \\
\text { Cheilanthes brandegeei }\end{array}$ & 1 \\
\hline
\end{tabular}


are attached to rocks in the middle to low intertidal zones to a depth of 1-6 m. Some algae may grow together and all represent an important food resource for sea turtles (Santamaría-Gallegos et al., 2003). The eel grass Zostera marina is common at shallow depths in Bahía Magdalena and Bahía Almejas. Carrera-González and de la Fuente (2003) estimate that this zone covers an area of $140 \mathrm{~km}^{2}$ (ca. $10 \%$ of the lagoons) as intertidal beds. Spartina foliosa is also a sea grass, but is an emergent life form up to $1.3 \mathrm{~m}$ high that grows in stands in shallow water and is generally associated with mangroves. Its biological importance and range needs more documentation.

Geographically restricted species are relevant because there are 20 endemic taxa, only four taxa have infraspecific status. Endemism includes one genus (Gongylocarpus, with one species and two subspecies). Table 2 shows these important taxa set; in this, 1 indicates the taxa restricted to the islands, 2 to the contiguous peninsular land, and 3 to both areas.

\section{Discussion}

The flora of this region, with ca. $4,268 \mathrm{~km}^{2}$ of land and $140 \mathrm{~km}^{2}$ of lagoons, has 506 taxa of vascular plants. Some known regional floras in Baja California Sur state, those from Sierra de La Giganta (729 taxa in 7,369 km²; León de la Luz et al., 2008) and the Cape Region dry tropical forest (520 taxa in 2,500 km² León de la Luz et al., 2012) are alike in surface size and number of taxa.

The vegetation landscape of the Bahía Magdalena plains contains scattered trees and some shrubs of relatively low diversity, which provide sparse canopy cover. Most of the species are herbaceous life forms and appear only after heavy rains (Table 1b). Vines and climbing species are moderately common. Hydrophytes are heterogeneous, found in marine and freshwater environments. Succulents endure not only low water availability, but alkaline and saline soil conditions. In most of the peninsula, the cardon Pachycereus pringlei is a conspicuous plant, a key species in the ecosystem because the high biomass per plant and plant density, but in this region, its density is relatively low and its size is small. It is practically absent on dunes and island and has low density in the other plant communities.

The 19 endemic taxa suggest a grade of singularity in the plant assemblages, mainly in the islands. Only two species endemic of cacti are protected by Mexican law (NOM059; SEMARNAT, 2010): Cylindropuntia santa-maria and Stenocereus eruca. Other cacti, Ferocactus townsendianus var. santa-maria is a poorly known species since only four specimens were located in 1952, which two were sent to botanical gardens according Lindsay (1996); Bravo and Sánchez-Mejorada (1991a) suggest that this may be an invalid taxon, but additional fieldwork is necessary to locate the only population reported. The family Asteraceae contributes two taxa, of which Bahiopsis subincisa is locally abundant above $100 \mathrm{~m}$ on the rocky slopes of the islands. Lyrocarpa xanti is other few known taxon, some specimens from the mid-peninsula have been designated with this name, but these could belong to some of the subspecies of the widespread L. coulteri. Asclepias masonii also has been poorly collected. Two specimens, one of Bahiopsis (Asteraceae) and other of Stenotis (Rubiaceae), seem to be novelties for the local flora, and require additional work.

In 1889, T. S. Brandegee collected sterile exemplars of Mimosa sp. on Isla Margarita with the annotation, "small bush neither in flower nor fruit". In 1928, J. N. Rose made a revision of Mimosaceae for North American flora and considered the inclusion of "Mimosa (?) Margaritae Rose, sp. nov" for such exemplars; since then nobody had collected additional material, but we found some exemplars during the fieldwork.

The grass family contributes two endemic taxa. Muhlenbergia brandegeei has an unusual distribution: Isla Margarita on the Pacific side of the peninsula and Isla Espíritu Santo on the Gulf of California. Tuctoria fragilis appears sporadically and massively on the llanos de Hiray, this species and Stenocereus eruca are the only endemics in the study area that are not found on the islands. The beach plant Helianthus niveus of the northern part of the peninsula was reported by Brandegee (1889) during his trip to Bahía Magdalena, but this taxon has never been collected again in locations south of the Desierto Vizcaino in the middle of the peninsula.

We found two gymnosperms on dunes, Ephedra californica and E. aspera (Ephedraceae), paleo-endemics of North American deserts, both extend their previous known range by almost $300 \mathrm{~km}$ southward following Turner et al. (1995) and Villanueva-Almanza and Fonseca (2011).

The endemic shrub Gongylocarpus fruticulosus in the Onagraceae has two varieties (see Table 2 and floristic list), both taxa are difficult to differentiate based on the type of vestiture. It is a common plant in the hills of Isla Margarita and Isla Magdalena islands, characterized by year-round blooms of large blue-magenta flowers. This is a good candidate for horticulture, similarly, the small Agave margaritae has this same potential.

From a purely floristic analysis, the Bahía Magdalena region has been considered a subunit of the Sonoran Desert province (Shreve, 1951; Shreve and Wiggins, 1964; Wiggins, 1980), based on landscape features and plant composition. The presence of great stands of mangrove highlights a tropical and subtropical feature, as well as some other species.

In the sarcocaulescent scrubland, the majority of the species present also occur in the dry tropical environment of the Cape Region, but two conspicuous species give here a particular touch Larrea tridentata and Atriplex canescens that are common in northern dry deserts. The marine plants reflect the influence of cold water current such as Zostera 
marina, Phyllospadix spp., and Spartina foliosa. There is no record of the rhizomatous grass Jouvea pilosa (J. Presl.) Scribn., which is common along the beaches of the Gulf of California; instead, Sporobolus virginicus occupies here the same niche. Both species converge on the Gulf of California side at the southern end of the peninsula. Avicennia germinans is a mangrove that has its northern limit just in this area.

Cattle grazing have been present in this area for at least two centuries. It is difficult to determine how livestock practices have impacted plant composition and structure. According to some anecdotal information from local elder population, mortality of plants is noticeable when rainfall is absent.

The farmed land area (Valle de Santo Domingo) has not expanded since the 1970s because the subsurface aquifer has been drawn down with consequent salt-water incursion; only $40-50 \%$ of the converted land area is currently in agricultural use (some $750 \mathrm{~km}^{2}$ in our study site polygon, considering also urban and sub-urban areas); these abandoned fields has been unable to progress in a secondary succession process, probably as a consequence of changes in the soil structure caused by mechanized farming. Along the coast, shrimp farms are a potential threat to mangrove stands. Invasion of exotic plants seem to be a minor concern, with the exception of some induced grasslands for cattle raising and buffel grass Pennisetum ciliare alongside the roads, this is an invasive plant that was introduced as pasture during 1960 decade. Also, Tamarix aphylla has been introduced in ranchos and fish camps as a shade plant, it is potentially an important invasive threat.

In summary, our study area contains several distinct landscapes. The most characteristic is the fog scrubland due its particularity in the peninsular context, but from a botanical perspective, the most important environmental units are the islands because of the many endemic species. Mexican environmental authority is evaluating the establishment of a Natural Protected Area within the surface that we surveyed. The boundaries are still undefined, although the marine zone seems to be the main objective. This includes mangroves, which are breeding area for marine animals that support several fisheries; the extensive beaches and adjacent coastal dunes, where at least five species of sea turtles lay eggs, and the relatively shallow bays and lagoons where gray whales (Eschrichtius robustus) breed in the winter and support an important ecotourism economy. If the initiative progresses authorities should include the rocky island areas where the polygon for Magdalena bay protected area will be defined, since an important number of endemic plants inhabit in these environments.

\section{Acknowledgements}

We thank Miguel Córdoba Matson of CIBNOR for English and editorial services. We also thank Miguel Domínguez for field assistance and fishermen of Puerto Cancun and Puerto Chale. Field trips in the Magdalena bay area were supported by Comisión Nacional para el Conocimiento y Uso de la Biodiversidad (CONABIO, grant HJ 002). Collection permits were issued by Dirección General de Vida Silvestre (SEMARNAT: SGPA/DGVS/03824/09, SGPA/DGVS/01928/10, SGPA/DGVS/07132/10, SGPA/ DGVS/07004/11, and SGPA/DGVS/09748/12). We are also grateful with reviewers of Biological Sciences for their valuable comments and suggestions in the review of the early manuscript.

\section{Literature cited}

Aguirre-Muñoz A., Bezaury-Creel J.E., de la Cueva H., MarchMifsut I.J., Peters-Recagno E., Rojas-González de Castilla S., and Santos del Prado-Gasca K. (Comp.). 2010. Islas de México, un Recurso Estratégico. Instituto Nacional de Ecología (INE), The Nature Conservancy (TNC), Grupo de Ecología y Conservación de Islas (GECI), Centro de Investigación Científica y de Educación Superior de Ensenada (CICESE), Mexico

Arriaga L., Vázquez-Domínguez E., González-Cano J., JiménezRosenberg R., Muñoz-López E., and Aguilar-Sierra V. (coord.). 2000a. Regiones terrestres prioritarias de México. Comisión Nacional para el Conocimiento y uso de la Biodiversidad. $<$ http://www.conabio.gob.mx/conocimiento/regionalizacion/ doctos/Tlistado.html> (consulted September 2012).

Arriaga L., Vázquez-Domínguez E., González-Cano J., JiménezRosenberg R., Muñoz-López E., and Aguilar-Sierra V. (coord.). 2000b. Regiones Marinas Prioritarias de México. Comisión Nacional para el Conocimiento y uso de la Biodiversidad. http://www.conabio.gob.mx/conocimiento/regionalizacion/ doctos/Mlistado.html (consulted june 2012).

Arriaga L., Moreno E. and Aguilar C. 2005. An overview of the floristic, richness and conservation of the arid regions of northern Mexico. In: Gottfried G.J., Gebow B.S., Eskew L.G., and Edminster C.B. (compilers). Connecting mountain islands and desert seas: biodiversity and management of the Madrean Archipelago II. May 11-15 2004; Tucson, AZ. pp 171-175. U.S. Department of Agriculture / Forest Service, Rocky Mountain Research Station, Proceedings RMRS-P-36.

Bentham G. 1844. The Botany of the Voyage of H.M.S. Sulphur, under the Command of Captain Sir Edward Belcher, during the years 1836-1842. Smith, Elder and Co., London.

Bizarro J.J. 2008. A review of the physical and biological characteristics of the Bahía Magdalena Lagoon Complex (Baja California Sur, Mexico). Bulletin, Southern California Academy of Sciences 107:1-24.

Brady K.U., Kruckeberg A.R., and Bradshaw H.D. Jr. 2005. Evolutionary ecology of plant adaptation to serpentine soils. Review of Ecology and Evolutionary Systematic 36:243-266.

Brandegee T.S. 1889. A collection of plants from Baja California. Proceedings of the California Academy of Sciences 2:117-225.

Bravo-Hollis H. 1978. Las Cactáceas de México. Vol. 1. Universidad Nacional Autónoma de México, Mexico D.F.

Bravo-Hollis H. and Sánchez-Mejorada H. 1991a. Las Cactáceas de México. Vol. 2. Universidad Nacional Autónoma de México, Mexico D.F.

Bravo-Hollis H. and Sánchez-Mejorada H. 1991b. Las Cactáceas 
de México. Vol. 3. Universidad Nacional Autónoma de México, Mexico D.F.

Brown D.E. (ed.). 1994. Biotic Communities: Southwestern United States and Northwestern Mexico. University of Utah Press, Salt Lake City.

Carrera-González E. and de la Fuente-de León G. 2003. Inventario y Clasificación de los Humedales en México. Parte I. Ducks Unlimited Inc., Pew Charitable Trust, North American Wetlands Conservation Act, Secretaria de Medio Ambiente y Recursos Naturales (SEMARNAT), Earth Satellite Corporation, Packard Foundation, Pro Esteros, Arizona Game \& Fish Departament, Embotelladoras ARCA y Ramsar. Mexico D.F..

CONABIO (Comisión Nacional para el Uso y Conocimiento de la Biodiversidad de México). 2002. Carta de Uso de Suelo y Vegetación, Instituto Nacional de Estadística, Geografía e Informática (INEGI) 1999, modificado por CONABIO. Formato vectorial. Escala 1:1,000,000. Mexico, D.F.

Crosswhite F.S. and Crosswhite C.D. 1984. A classification of the life forms of the Sonoran Desert, with emphasis on the seed plants and their survival strategies. Desert Plants 5:131-161.

Danemann G. 2010. Propuesta para la creación de la Reserva de la Biosfera Complejo Lagunar Bahía Magdalena, Baja California Sur, Resumen Ejecutivo. PRONATURA Noroeste. Manuscrito sometido a la Comisión Nacional de Areas Protegidas (CONANP). La Paz, BCS.

Daniel T.F. 1997. The Acanthaceae of California and the Peninsula of Baja California. Proccedings of the California Academy of Sciences 49:309-403.

DEGETENAL [Dirección General de Geografía del Territorio Nacional]. 1981. Carta de Uso del Suelo y Vegetación 1:1,000,000. Hoja La Paz. Secretaría de Programación y Presupuesto, Coordinación General de los Servicios Nacionales de Estadística, Geografía e Informática, Mexico D.F.

Funes-Rodríguez R., Gómez-Gutiérrez J., and Palomares-García R. Eds. 2007. Estudios Ecológicos en Bahía Magdalena. Centro de Investigaciones Biológicas del Noroeste S,C., Centro Interdisciplinario de Ciencias Marinas, Instituto Politécnico Nacional (IPN), México D.F.

García-de Miranda E. 1973. Modificaciones al sistema de clasificación climática de Köppen (para adaptarlo a las condiciones de la República Mexicana). Instituto de Geografía, Universidad Nacional Autónoma de México., Mexico D.F.

Gentry H.S. 1978. The Agaves of Baja California. Ocasional Papers of the California Academy of Sciences 130: 1-119

Gould F.W. and Moran R. 1981. The Grasses of Baja California, Mexico. Memoirs of San Diego Society of Natural History 12: $1-140$

González-Zamorano P., Nava-Sánchez E.H., León-de la Luz J.L. and Díaz-Castro S.C. 2011. Patrones de distribución y determinantes ambientales de los manglares peninsulares. pp. 67-103. In Félix-Pico E.F., Serviere-Zaragoza E., Riosmena-Rodríguez R. and León de la Luz J.L. (eds). Los Manglares de la Península de Baja California. Centro de Investigaciones Biológicas del Noroeste, La Paz, Baja California Sur.

Hickman C.J. ed. 1993. The Jepson Manual: Higher plants of California. University of California Press, Berkeley and Los Angeles, California.

Johnson A.F. 1977. A survey of the strand and dune vegetation along the Pacific and southern Gulf coast of Baja California, Mexico. Journal of Biogeography 4: 83-99.
León-de la Luz J. L., Rebman J., Domínguez-León M. and Domínguez-Cadena R. 2008. The vascular flora of the Sierra de La Giganta in Baja California Sur, Mexico. Revista Mexicana de Biodiversidad 79:29-65.

León-de la Luz J.L., Domínguez-Cadena R. and Domínguez-León M. 2012. Florística de la Selva Baja Caducifolia de la Península de Baja California, México. Botanical Sciences 90:143-162.

Lindsay G. 1996. The genus Ferocactus: taxonomy and ecology: explorations in USA and Mexico. Tireless Termite Press. San Diego.

Lot A. and Chiang F. 1986. Manual de herbario: Administración y manejo de de colecciones, técnicas y preparación de ejemplares botánicos. Consejo Nacional de Flora de México, México, D.F.

Martin P.S., Yetman D.A., Fishbein M.E., Jenkins P.D., Van Devender T.R., and Wilson R.K. 1998. Gentry's Río Mayo Plants: The tropical deciduous forest and environs of Northwest Mexico. The University of Arizona Press, Tucson.

Medina E. 1995. Diversity of life forms in higher plants in neotropical dry forests. In: Bullock S., Mooney H.A., and Medina E. Seasonally Dry Tropical Forests, pp 221-242. Cambridge University Press, New York.

Murillo J.M., Osborne R.H, and Gorsline D.S. 1994. Sources of beach sand at Creciente Island, Baja California Sur, Mexico: Fourier grain-shape analysis. Ciencias Marinas 20:243-266

Nash III T.H., Ryan B.D., Gries C. and Bungart F. (eds.). (2002). Lichen Flora of the Greater Sonoran Desert Region. Lichens Unlimited, Arizona State University. Tempe.

Ortíz-Hernández L.E., Escamilla-Casas J.C., Flores-Castro K., Ramírez-Cardona M. and Acevedo-Sandoval O. 2006. Características geológicas y potencial metalogenético de los principales complejos ultramáficos-máficos de México. Boletín de la Sociedad Geológica de México 57:161-181.

Rebman J.P. and Roberts N.C. 2013. Baja California: Plant Field Guide. San Diego Natural History Museum, Sunbelt Publications, San Diego.

Rzedowski J. 1973. Geographical relationships of the flora of Mexican dry regions. In: Graham A., Ecological Society of America, American Society of Plant Taxonomists Eds. Vegetation and Vegetational History of Northern Latin America: papers presented as part of a symposium at the American Institite of Biological Sciences meetings, Bloomington, Ind. (USA), pp 61-72, Elsevier Scientific, Amsterdam.

Rzedowski J. 1978. Vegetación de México. Editorial Limusa. México, D.F.

Rzedowski J. 1979. Los bosques secos y semi-húmedos de México con afinidades neotropicales. In: Ravinovich J. and Halffter G. Eds. Tópicos de Ecología Contemporánea, pp 37-46, Fondo de Cultura Económica, México D.F.

Santamaría-Gallegos N.A., Félix-Pico E.F., Sánchez-Lizaso J.L. and Riosmena-Rodríguez R. 2007. Ecología de la fanerógama Zostera marina en el sistema lagunar Bahía Magdalena-Bahía Almejas. In: Funes-Rodríguez R., Gómez-Gutiérrez J., and Palomares-García R. Eds. Estudios Ecológicos en Bahía Magdalena, pp 101-112, Centro de Investigaciones del Noroeste S.C., Centro Interdisciplinario de Ciencias Marinas, Instituto Politécnico Nacional (IPN), México.

SEMARNAT [Secretaría del Medio Ambiente y Recursos Naturales]. 2010. Norma Oficial Mexicana NOM-059-SEMARNAT-2010, Protección ambiental - Especies nativas de México 
de flora y fauna silvestres - Categorías de riesgo y especificaciones para su inclusión, exclusión o cambio - Lista de especies en riesgo. Diario Oficial de la Federación. 2da Sección, 30 de diciembre de 2010.

Shreve F. and Wiggins I.L. 1964. Vegetation and Flora of the Sonoran Desert, 2 vols. Stanford University Press, Palo Alto.

Spears P. 2006. A Tour of the Flowering Plants based on the Classification System of the Angiosperm Phylogeny Group. Missouri Botanical Garden Press, St. Louis, MO.

Tropicos. 2013. Tropicos.org. Missouri Botanical Garden. <http:// www.tropicos.org> (accessed 15 August 2013)

Turner R.M., Bowers J.E. and Burgess T.L. 1995. Sonoran Desert Plants, an Ecological Atlas. The University of Arizona Press, Tucson.

Unisys Weather. 2013. Eastern Pacific Tropical Storm Tracking by Year. < http://weather.unisys.com/hurricane/e_pacific/index. html $>$ [accessed 30 July 2013].

Received: March 19th, 2014

Accepted: August 6th, 2014
Van Devender T.R., Sanders A.C., Wilson R.K. and Meyer S.A. 2000. Vegetation, flora, and seasons of the Rio Cuchujaqui, a tropical deciduous forest near Alamos, Sonora, Mexico. In: Yetman Y.A. and Robichaux R.H. Eds. The tropical deciduous forest of Alamos: biodiversity of a threatened ecosystem in Mexico, pp. 36-101, University of Arizona Press, Tucson.

Villanueva-Almanza L. and Fonseca R.M. 2011. Revisión taxonómica y distribución geográfica de Ephedra (Ephedraceae) en México. Acta Botanica Mexicana 96:79-116.

Wiggins I.L. 1960. The origins and relationships of the land flora. The biogeography of Baja California and adjacent seas. Systematic Zoology 9:148-165.

Wiggins I. L. 1980. Flora of Baja California. Stanford University Press, Palo Alto.

Wilson E.O. Ed. 1988. Biodiversity. National Academies Press, Washington, D.C. 


\begin{tabular}{rll}
\hline Abb. & Collector name & Herbarium \\
AMN & Alfonso Medel Narváez & HCIB \\
MDL & Miguel Domínguez León & $\mathrm{HCIB}$ \\
RDC & Raymundo Domínguez Cadena & $\mathrm{HCIB}$ \\
JLLL & José Luis León de la Luz & $\mathrm{HCIB}$ \\
JPN & José Juan Pérez Navarro & $\mathrm{HCIB}$ \\
JPR & Jon Paul Rebman & $\mathrm{SD}$ \\
RVM & Reid Vernon Moran & $\mathrm{SD}, \mathrm{DS}$ \\
RMB & Robert Mitchel Beauchamp & $\mathrm{SD}$ \\
TSB & Townshend Stith Brandegee & $\mathrm{UC}$ \\
PJM & Peta J. Mudie & $\mathrm{UC}$ \\
GLW & Grady L. Webster & $\mathrm{UC}$ \\
JHT & John Howell Thomas & $\mathrm{SD}$ \\
GL & George Lindsay & $\mathrm{SD}, \mathrm{DS}$ \\
HCS & Hugo Cota Sánchez & $\mathrm{SD}$ \\
JDR & José Delgadillo Rodríguez & $\mathrm{BCMEX}$ \\
JRR & John Raymond Reeder & $\mathrm{SD}, \mathrm{ARIZ}$ \\
\hline
\end{tabular}

FERNS (Pteridophyta)

\section{MARSILEACEAE}

Marsilea fournieri C. Chr. [M. vestita], Hf. HCIB: JLLL 11262, MDL 4466, MDL 4638.

PTERIDACEAE

Argyrochosma peninsularis (Maxon et Weath.) Windham. [Notholaena p.], Ph. HCIB: JLLL 11372.

Cheilanthes brandegeei D.C. Eaton, Ph. HCIB: JLLL 1336, UC: TSB s/n.

Notholaena californica D.C. Eaton subsp. leucophylla Windham, Ph. HCIB: JLLL 11371, SD: JPR 4801.

Notholaena sulphurea (Cav.) J. Sm. [Cheilanthes s.], Ph. UC: TSB s/n.

\section{GYMNOSPERMS}

\section{EPHEDRACEAE}

Ephedra aspera Engelm. ex S. Watson [E. peninsularis], Sh. HCIB: RDC 3253, SD: RMB 2152.

Ephedra californica S. Watson, Sh. AMN 2011-321 HCIB, UC: TSB s/n.

\section{ARISTOLOCHIACEAE}

\section{ANGIOSPERMS}

Magnolides

Aristolochia watsonii Wootton et Standl., Ph. HCIB: MDL 4649. Hierba del indio.

\section{ACANTHACEAE}

\section{Eudicots}

Carlowrightia arizonica A. Gray, Ph. HCIB: AMN 2011-235.

Dicliptera resupinata (Vahl) Juss., Ph. HCIB: JLLL 481, 581, 1207, MDL 4653.
Holographis virgata subsp. glandulifera (Leonar et C.V. Morton) (Harv. ex Benth. \& Hook. f.) T.F. Daniel. [Berginia v.], An. HCIB: RDC 3768.

Justicia californica (Benth.) D.N. Gibson. [Beloperone c.], Ph. UC: TSB s/n. Chuparrosa.

Justicia insolita Brandegee, Ph. HCIB: RDC 3298. Chuparrosa. Justicia palmeri Rose, Ph. HCIB: JLLL 1510. Chuparrosa.

AIZOACEAE

*Mesembryanthemum crystallinum L., Sc. HCIB: AMN 2012 036. Hielito.

Sesuvium portulacastrum (L.) L., Pr. HCIB: AMN 2011-174, 2011-182, 2011-200, 2011-216, 2011-230, 2011-259, 2012-030, JJPN 501, 546, 565, 575, JLLL 537, 1393, 1476, 1498, 11247, 11405, MDL 4740, RDC 3508, 3680, 3688, 3784, SD: CFH 345, RMB 2130, UC: TSB s/n.

Sesuvium verrucosum Raf., Pr. HCIB: JLLL 11246, MDL 4772. Trianthema portulacastrum L., Pr. HCIB: JLLL 534, 11528, MDL 4430, RDC 3612, SD: JHT 8402. Verdolaga de cochi.

\section{AMARANTHACEAE}

Amaranthus fimbriatus (Torr.) Benth. ex S. Watson, An. HCIB: AMN 2012-154, 2012-165, MDL 4415, RDC 3836. Quelite.

Amaranthus hybridus L., An. HCIB: RDC 3920. Quelite.

Amaranthus palmeri S. Watson, An. HCIB: AMN 2012-082, JJPN 513, JLLL 540, 1242, 11489, MDL 4548, s/n, RDC 3161, 3568, 3746, 3835, UC: TSB s/n. Quelite.

Amaranthus watsonii Standl., An. HCIB: JJPN 589, JLLL 11200, 11295, RDC 3552, 3606, 3710, 3728, 3750. Quelite.

Celosia floribunda A. Gray, Sh. HCIB: JLLL 1200. Bledo.

Iresine alternifolia S. Watson [Dicraurus a.], Ph. UC: TSB s/n.

ANACARDIACEAE

Pachycormus discolor (Benth.) Coville, Sc. HCIB: RDC 3281, 3825, SD: RMB 2119, RVM 10825, UC: TSB s/n. Copalquín.

APIACEAE (UMBELLIFERAE)

Arracacia brandegeei J.M. Coult. et Rose, Ph. UC: TSB s/n. Chuchupate.

*Coriandrum sativum L., Ph. UC: TSB s/n. Perejil.

Eryngium nasturtiifolium Juss. ex F. Delaroche., An. HCIB: JLLL 11259, RDC 3172.

APOCYNACEAE (inc. ASCLEPIADACEAE)

Asclepias albicans S. Watson, Sc. UC: TSB s/n.

Asclepias masonii Woodson, Sc. HCIB: AMN 2012-020, SD: RMB 2106, RVM 10815.

Asclepias subulata Decne, Sc. HCIB: JLLL 11220, MDL 4609, RDC 3582, SD: FG 9789.

Cynanchum californicum (Benth.) Moran, [Metastelma c.] Pr. HCIB: MDL 4453, RDC 3267, UC: TSB s/n.

Cynanchum palmeri var. peninsulare (S.F. Blake) I.M. Johnst., [Seutera p.],Vi. HCIB: MDL 4559, JLLL 11821.

Funastrum arenarium (Decne ex Benth.) Liede. [Sarcostemma arenaria], Pr. HCIB: AMN 2011-169, 2011-175, 2011-218, 
2011-227, 2011-262, 2012-037, 2012-151, JJPN 508, 588, MDL 4826, RDC 3497, 3651, UC: UC: TSB s/n

Funastrum cynanchoides (Decne.) Schltr. var. hartwegii (Vail) Krings, [Sarcostemma c.; Philibertia linearis], Pr. HCIB: JLLL 480, 1373, 1403, MDL 4651. TSB s/n

Funastrum peninsulare (Decne. ex Benth.) Liede. [Cynanchum p.], Vi. HCIB: JLLL 1525, 11381.

Matelea pringlei (A. Gray) Woodson, Pr. UC: TSB s/n.

Vallesia glabra (Cav.) Link., Ph. HCIB: RDC 3525, SD: FG 9790. Otatave.

ASTERACEAE

Amauria brandegeeana (Rose) Rydb. [Perityle b.], An. SD: FG 9792, PJM 840.

Ambrosia ambrosioides (Cav.) W.W. Payne [Franseria a.], Sh. HCIB: JLLL 1365. Chicura.

Ambrosia bryantii (Curran) W.W. Payne [Franseria b.], Alfilerillo. Sh. HCIB: JLLL 574, 1249, 1323, 1435, 11304, MDL 4767, RDC 3614, UC: TSB s/n.

Ambrosia camphorata (Greene) W.W. Payne [Franseria c.], Sh. HCIB: AMN 2011-332, JLLL 578, 1241, 11258, RDC 1808, SD: JPR 4814. Istafiate.

Ambrosia canescens A. Gray, Sh. HCIB: RDC 3339.

Ambrosia chenopodiifolia (Benth.) W.W. Payne [Franseria ch.], Sh. BCMEX: JPR 1712, HCIB: JLLL 1442, RDC 3133, SD: RMB 2160, RVM 10824, UC: TSB s/n. Istafiate.

Ambrosia confertiflora DC. [Franseria C.], Sh. HCIB: AMN 2011-373, JLLL 504, 1265, 2006-08, MDL 4757, RDC 3165, 3529, SD: JPR 7753.

Ambrosia deltoidea (Torr.) W.W. Payne [Franseria d.], Sh. HCIB: MDL 2395, 4641, 4763, RDC 3343.

Ambrosia divaricata (Brandegee) W.W. Payne [Franseria d.], Sh. HCIB: JLLL 7670, MDL 4521, 4613, RDC 3261, SD: JPR 4794.

Ambrosia magdalenae (Brandegee) W.W. Payne [Franseria m.], Sh. HCIB: AMN 2011-238, 2011-266, JLLL 509, 1396, 11473, 11505, s/n, MDL 4416, 4459, 4475, 4520, RDC 3301, 3515, 3585, 3638, 3748, UC: TSB s/n.

Ambrosia monogyra (Torr. et A. Gray) Strother et B.G. Baldwin [Hymenoclea m.], Ph. HCIB: RDC 3528. Romerillo.

Baccharis salicifolia (Ruiz et Pav.) Pers., Sh. HCIB: JLLL 495, 1236, SD: JHR 890. Guatamote.

Baccharis sarothroides A. Gray, Sh. HCIB: JLLL 507, 514, 11190, RDC 3492, 3530. Guatamote.

Bahiopsis chenopodina (Greene) E.E. Schill. et Panero [Viguiera deltoidea var. c.], Ph. HCIB: AMN 2011-353, JLLL 1418, 11299, MDL 4479, 4528, 4658, RDC 3163, 3200, 3248, 3258, 3292, 3586, 3829, SD: GLW 19572. Tacote.

Bahiopsis deltoidea (A. Gray) E.E. Schill. et Panero [Viguiera d.], Sh. UC: TSB s/n. Tacote.

Bahiopsis subincisa (Benth.) E.E. Schill. et Panero [Viguiera s.], Ph. HCIB: AMN 2011-328, 2012-013, JLLL 1345, 1378,
1484, 11484, SD: JPR 4774, RMB 2115, Ph. RVM 3531, RVM 10814, UC: TSB s/n.

Bahiopsis triangularis (M.E. Jones) E.E. Schill. et Panero [Viguiera t.], Sh. SD: RVM 10818.

Bajacalia tridentata (Benth.) Loockerman, B.L. Turner et R.K. Jansen [Porophyllum tridentatum], Sh. HCIB: AMN 2011329, 2011-365, JLLL 1444, 11490, RDC 3910, SD: GLW 19585, JPR 4804, RMB 2122, 2144, RVM 4181, 10806, BCMEX: JPR 1713, JPR 2792, 4804b, SD: GLB 19585; UC: TSB s/n.

Bebbia atriplicifolia (A. Gray) Greene [B. juncea var. a.], Ph. HCIB: RDC 3543. Apan.

Bebbia juncea (Benth.) Greene, Sh. HCIB: AMN 2011-364, 2012-006, JLLL 1415, RDC 3262, 3830, 3905, SD: GLW 19573, RMB 2101, UC: TSB s/n. Apan.

Bebbia juncea (Benth.) Greene var. aspera Greene, Ph. HCIB: JLLL 11476. Apan.

Blumea viscosa (Mill.) V.M. Badillo [Conyza v.], An. HCIB: AMN 2011-234, JLLL 501, MDL 2391.

Boeberastrum anthemidifolium (Benth.) Rydb. [Dyssodia a.], An. HCIB: JLLL 557, 6081, MDL 736, 2369, 4423, 4572, RDC 3336, SD: JRR 7136, PJM 839.

Brickellia hastata Benth., Ph. HCIB: JLLL 1352, SD: JPR 4797, UC: TSB s/n.

Cirsium occidentale (Nutt.) Jeps. var. californicum (A. Gray) D.J. Keil et C.E. Turner [C. californicum], An. HCIB: JLLL 1220.

Coreocarpus dissectus (Benth.) S.F. Blake, Sh. BCMEX: JPR 1720, JPR 2798, HCIB: AMN 2011-367, JLLL 1314, 11410, 11498, MDL 4619, RDC 3305, 3833, SD: GLW 19591, JPR 4769, RMB 2099, RVM 4178, 10807, UC: TSB s/n.

Coreocarpus parthenioides Benth. var. parthenioides, An. HCIB: AMN 2011-358, JLLL 11512, RDC 3919.

Coreocarpus parthenioides Benth. var. heterocarpus (A. Gray) S.F. Blake, An. HCIB: JLLL 483, 558, 1343, MDL 4418, 4519, RDC 3177, 3226, 3837, SD: JPR 4782, UC: TSB s/n.

Eclipta prostrata (L.) L., Pr. HCIB: JLLL 492, 1208, RDC 3150, UC: TSB s/n.

Encelia conspersa Benth., Sh. HCIB: JLLL 1416, 1437, 1438, RDC 3283, 3908, SD: GLW 19584, JPR 4778, UC: TSB $\mathrm{s} / \mathrm{n}$.

Encelia farinosa var. phenicodonta (S.F. Blake) I.M. Johnst., Sh. HCIB: JLLL 1246.

Encelia halimifolia Cav., Sh. HCIB: AMN 2011-219, 2011-265, JLLL 1371, 1390, 1517, 11483, RDC 3901.

Encelia palmeri Vasey et Rose, Ph. HCIB: AMN 2011-341, JJPN 537, JLLL 520, 542, 11213, 11221, 11308, 11379, s/n, MDL 2392, 4451, 4485, 4535, 4657, 4751, RDC 3228, 3481, 3511, 3578, 3623, 3624, UC: TSB s/n.

Encelia ventorum Brandegee, Ph. HCIB: AMN 2011-222, 2011-263, JJPN 547, SD: PJM 833, UC: TSB s/n. 
Gnaphalium palustre Nutt., An. HCIB: RDC 3142. Gordolobo.

Helenium thurberi A. Gray, Ph. HCIB: JLLL 1366.

Helianthus niveus (Benth.) Brandegee, Ph. UC: TSB s/n.

Heliopsis parvifolia A. Gray var. rubra (T.R. Fisher) Wigg. Ph. UC: TSB s/n.

Hofmeisteria fasciculata (Benth.) Walp., Sc. BCMEX: JPR 1718, HCIB: AMN 2012-018, JLLL 1346, 1439, 11492, MDL 4623, RDC 3811, 3915, SD: GLW 19571, JPR 4788, 4815, RMB 2097, RVM 3536, 10808, UC: TSB s/n.

Isocoma menziesii (Hook. et Arn.) G.L.Nesom [Haplopappus m.], Sh. HCIB: AMN 2011-239, 2012-027, 2012-159, JLLL 1398, 11245, 11386, MDL 4735, RDC 3114, 3601, 3659, 3664, 3696, 3697, 3709, UC: TSB s/n.

*Laennecia coulteri (A. Gray) G.L Nesom [Conyza c.], Ph. HCIB: MDL 4648, RDC 3134.

Malacothrix xanti A. Gray, An. HCIB: RDC 3145, 3254, SD: JPR 4771, UC: TSB s/n.

Nicolletia trifida Rydb., Ph. HCIB: JLLL 516, MDL 4650.

Palafoxia arenaria Brandegee, Ph. UC: TSB s/n.

Palafoxia linearis (Cav.) Lag., Ph. HCIB: AMN 2011-240, $2011-$ 264, JLLL 1527, MDL 4833.

Pectis angustifolia Torr., An. HCIB: RDC 3157.

Pectis multiseta var. ambigua (Fernald) D.J.Keil, An. HCIB: JLLL 1252, MDL 4446, 4450, 4639, RDC 3178.

Pectis papposa Harv. et A. Gray, An. HCIB: AMN 2012-170, JJPN 1309, MDL 4540, RDC 3198, 3534, 3972.

Pelucha trifida S. Watson, Ph. HCIB: JLLL 553, MDL 3858.

Perityle aurea Rose, An. HCIB: JLLL 570, RDC 3128, 3264.

Perityle californica Benth., An. HCIB: AMN 2012-029, JLLL 1341, MDL 4538, 4620, 4636, RDC 1805, 3617, 3676, SD: JLLL 6073, JPR 4802, UC: TSB s/n.

Perityle crassifolia var. robusta (Rydb.) Eyerly, An. SD: RMB 2156, RVM 3537.

Perityle emoryi Torr., An. HCIB: JLLL 543, 1332, 1434, MDL 4428, 4545, 4771, RDC 3120, SD: FG 9793, GLW 19589.

Perityle fitchii Torr. ex A. Gray, An. UC: TSB s/n.

Perityle incompta Brandegee, An. HCIB: JLLL 569, 1306, MDL 4818, SD: JPR 4786.

Pluchea odorata (L.) Cass. Hf. HCIB: RDC 2894. Cachanilla.

Porophyllum gracile Benth., Sh. HCIB: AMN 2011-326, 2012016, 1338, JLLL 11497, MDL 4612, RDC 3193, 3743, UC: TSB s/n. Hierba del Venado.

Pseudognaphalium stramineum (Kunth) Anderb. [Gnaphalium s.], An. HCIB: JLLL 1361.

*Sonchus oleraceus L., An. HCIB: RDC 3126. Lechuguita.

Stephanomeria virgata Benth., An. HCIB: JLLL 1317.

Trixis angustifolia DC., Sh. HCIB: AMN 2011-336, JLLL 11485, MDL 4624, 4761, RDC 3482, UC: TSB s/n.

Trixis californica Kellogg., Sh. HCIB: AMN 2012-022, JLLL 1330, RDC 3904, SD: GLW 19580, JPR 4805, RMB 2120.

* Verbesina encelioides (Cav.) Benth. et Hook f. ex A. Gray, Ph. HCIB: JLLL 505, 577, RDC 3531.
Xanthium strumarium L., An. HCIB: JLLL 477, 1234.

Xylothamia diffusa (Benth.) G.L. Nesom [Ericameria d., Haplopappus sonoriensis], Sh. HCIB: JLLL 11218, 11285, MDL 4481, 4505, 4563, 4750, RDC 3296, 3491, 3551, 3742, 3762, SD: RMB 2146, UC: TSB s/n.

\section{BATACEAE}

Batis maritima L., Pr. HCIB: AMN 2011-184, JJPN 540, 577, JLLL 1499, 11252, MDL 4591, 4738, 4828, RDC 3504, 3681, 3693, 3699, 3780, s/n, SD: JPR 4783, PJM 852, RMB 2133.

BIXACEAE

Amoreuxia palmatifida DC., Ph. HCIB: JJPN 1306, SD: MDL 2837. Zaya.

BORAGINACEAE

Bourreria sonorae S. Watson, Sh. HCIB: MDL 4628, RDC 3275, SD: RMB 2121. Chocolatillo.

Cordia curassavica (Jacq.) Roem. et Schult., Sh. HCIB: JLLL 511, MDL 4608, 4622, 4730, 4817, RDC 3273, UC: TSB s/n. Manzanita.

Cryptantha angelica I.M. Johnst., An. SD: JPR 4775.

Cryptantha angustifolia (Torr.) Greene, An. SD: CD 2010.

Cryptantha echinosepala J.F. Macbr., An. HCIB: RDC 3257, SD: JPR 4775b, UC: TSB s/n.

Cryptantha grayi var. cryptochaeta I.M. Johnst., An. HCIB: RDC 3839.

Cryptantha maritima (Greene) Greene, An. HCIB: MDL 4434, RDC 3139, UC: TSB s/n.

Cryptantha micromeres (A. Gray) Greene, An. HCIB: MDL 4816, UC: TSB s/n, TSB s/n.

Heliotropium angiospermum Murray, Pr. HCIB: MDL 2364.

Heliotropium curassavicum var. oculatum (A. Heller) I.M. Johnst. ex Tides, Pr. HCIB: AMN 2012-031, JLLL 1308, 1441, 11248, MDL 4410, 4632, 4809, 4810, RDC 3179, SD: RMB 2140, UC: TSB s/n.

Heliotropium hintonii (I.M. Johnst.) I.M. Johnst., Pr. HCIB: JLLL 1262, RDC 3171.

Heliotropium procumbens Mill., Pr. HCIB: RDC 3340. Hierba del alacrán.

Tiquilia cuspidata (I.M. Johnst.) A.T. Richardson [Coldenia c.], Ph. HCIB: JLLL 11265.

BRASSICACEAE

Dithyrea californica Harv. var. clinata (J.F. Macbr. et Payson) Wigg., An. HCIB: JLLL 1406.

Dryopetalon palmeri (S. Watson) O.E. Schulz., An. HCIB: RDC 3259.

Dryopetalon purpureum Rollins, An. HCIB: MDL 4616, SD: GLW 19581, JPR 4768, RVM 3532.

Eruca vesicaria (L.) Cav. [Brassica v.], An. HCIB: JLLL 2006-05, SD: JLLL 2006-13.

Lepidium medium Greene, An. HCIB: JLLL 1237.

Lepidium virginicum L., An. HCIB: MDL 4465.

Lyrocarpa xanti Brandegee, An. UC: TSB s/n. 
Rorippa teres (Michx.) Stuckey, Hf. [Sisymbrium walteri], HCIB: JLLL 490, 1374. Berro.

Sisymbrium irio L., An. HCIB: JLLL 11264, RDC 3162. Moztacilla.

Streptanthus arizonicus S. Watson, [Disaccanthus a.], An. HCIB: MDL 2611.

Thelypodiopsis versicolor (Brandegee) Rollins [Sisymbrium v.], An. UC: TSB s/n.

BURSERACEAE

Bursera hindsiana (Benth.) Engl., Sc. HCIB: AMN 2011-362, 2012-005, 2012-076, JJPN 1305, JLLL 527, 1432, 11208, 11526, s/n, MDL 4440, RDC 2014, 3512, 3572, 3621, 3654, 3828, SD: RMB 2116, UC: TSB s/n. Copal rojo.

Bursera littoralis León de la Luz et Pérez-Navarro, Sc. HCIB: JJPN 1518, JLLL 11391.

Bursera microphylla A. Gray, Sc. HCIB: JLLL 11212, 11530, s/n, MDL 4439, RDC 3513, 3569, 3596, 3670, 3723, 3769, s/n, SD: RMB 2167, UC: TSB s/n. Torote rojo.

Bursera odorata Brandegee (B. fagaroides var. o.), Sc. HCIB: JLLL 1389, 1524, MDL 4477, 4759, RDC 3199, 3358, 3499. Torote blanco.

CACTACEAE

Cochemiea halei (Brandegee) Walton [Mammillaria h.], Sc. HCIB: AMN 2011-372, JLLL 1357, 11417, SD: JPR 2788, RVM 3539, 10828, UC: TSB s/n.

Cylindropuntia alcahes (F.A.C. Weber) F.M. Knuth, Sc. BCMEX: JPR 4827, HCIB: AMN 2011-194, 2011-241, 2011258, JLLL 1254, 1448, 7665, 11194, 11230, 11268, 11290, 11406, s/n, s/n, MDL s/n, RDC 3557, 3604, 3628, 3669, 3701, 3733, 3754, SD: JPR 1700, 1707, 2789, $1707 \mathrm{~b}$.

Cylindropuntia cholla (F.A.C. Weber) F.M. Knuth, Sc. HCIB: RDC 3467, 3514, 3538, 3579, 3611, 3643, 3664. Choya.

Cylindropuntia lindsayi (Rebman) Rebman, Sc. HCIB: JPR 1392, RDC 3140, 3665.

Cylindropuntia santamaria (E.M. Baxter) Rebman, Sc. HCIB: MDL s/n, SD: JDR 4831, JPR 2785.

Echinocereus barthelowanus Britton et Rose, Sc. HCIB: JLLL 11403, 11416, 11524, SD: GL 2252, JDR 4830, JPR 2787.

Echinocereus brandegeei (J.M. Coult.) K. Schum., Sc. HCIB: AMN 2011-340, JLLL 11368, 11374, RDC 3523.

Echinocereus maritimus (M.E. Jones) K. Schum., Sc. HCIB: RDC 3521, 3615.

Ferocactus townsendianus Britton et Rose var. townsendianus [F. peninsulae var. t.], Sc. HCIB: AMN 2011-371, JLLL 579, 1255, 1328, 1449, 11204, 11236, 11281, 11305, 11399, 11401, RDC 3361, 3584, 3649, 3717, 3763, SD: GL 2160, HCS 8017, 8019, HCS 8021, JPR 2804, 4828. Biznaga.

Ferocactus townsendianus Britton et Rose var. santa-maria (Britton et Rose) Linds. [F. s-m.] Sc. SD: GL.2160.

Lophocereus schottii (Engelm.) Britton et Rose var. schottii [Pachycereus s.], Sc. HCIB: JLLL 11418, SD: JPR 2801. Garambullo.
Mammillaria dioica K. Brandegee, Sc. BCMEX: JPR 2786, 4826, HCIB: AMN 2011-242, JLLL 1316, 11366, 11369, 11400, 11404, 11522, MDL s/n, RDC 3560, 3843, SD: RVM 7458. Viejito.

Mammillaria hutchisoniana (H.E. Gates) Boed. ex Backeb. et F.M. Knuth, Sc. HCIB: JLLL 1325, 11239, 11302, 11419, RDC 3605, 3639, 3675, 3755. Viejito.

Opuntia pycnantha Engelm., Sc. BCMEX: JPR 4829, HCIB: AMN 2012-002, JLLL 1358, 1447, 11407, s/n, RDC 3286, 3520, SD: CFH 348, GL 2162, 2252a, JPR 1389, 1708, 2790, RMB 2128.

Pachycereus pringlei (S. Watson) Britton et Rose, Sc. HCIB: JLLL 1257, 1446, 11193, 11226, 11278, 11300, 11420, s/n, MDL s/n, s/n, RDC 3554, 3594, 3631, 3663, 3727, 3753, UC: TSB s/n. Cardón

Peniocereus striatus (Brandegee) Buxb. [Wilcoxia striata], Sc. BCMEX: JPR 2835, HCIB: AMN 2011-342, JLLL 1356, 11303, 11521, SD: JHT 8391, JPR 4825, RVM 21336. Rajamatraca.

Stenocereus eruca (Brandegee) A.C. Gibson et K.E. Horak [Machaerocereus e.], Sc. BCMEX: JPR 1391, HCIB: JLLL 508, 1445, 11402, JPR 2869, MDL 2397, 3909, s/n, RDC 3667, 3715, SD: RVM 21334 SD, 21363, UC: TSB s/n. Chirinola.

Stenocereus gummosus (Engelm.) A.C. Gibson et K.E. Horak [Machaerocereus g.], Sc. HCIB: AMN 2011-195, 2011243, JLLL 1360, 11196, 11231, 11269, 11288, 11408, 11520, 1254b, s/n, JPR 2799, MDL s/n, RDC 3553, 3593, RDC 3627, 3661, 3706, 3725, 3756, s/n, SD: RVM 21335, UC: TSB s/n. Pitaya agria.

Stenocereus thurberi (Engelm.) Buxb. var. thurberi [Lemairocereus t.], Sc. HCIB: JLLL 11195, 11232, 11270, 11289, MDL s/n, RDC 3616, 3678, 3744. Pitaya dulce.

\section{CAPPARACEAE (CAPPARIDACEAE)}

Capparis atamisquea Kuntze. [Atamisquea emarginata], Sh. BCMEX: JPR 2794, HCIB: JLLL 11201, 11228, 11272, 11310, MDL 4494, RDC 3488, 3565, 3618, 3734, 3759, s/n, SD: JPR 1711b. Juaiven.

Forchhammeria watsonii Rose, Sc. BCMEX: JPR 1711. Jito, Palo San Juan.

Koeberlinia spinosa Zucc. Sh. HCIB: MDL 734, RDC 3334, 3579, 3653, 3737, 3776. Chaparro amargoso.

\section{CARYOPHYLLACEAE}

Achyronychia cooperi Torr. et A. Gray, An. HCIB: RDC 876, 3808, UC: TSB s/n.

Drymaria holosteoides Benth., Pr. HCIB: JLLL 1333, 11499, RDC 3917, SD: CD 2032, JHT 8404, JPR 4770, RVM 3535.

Drymaria holosteoides Benth. var. crassifolia (Benth.) J.A. Duke, Pr. HCIB: JLLL 1426, MDL 4512, 4629, RDC 3211, UC: TSB s/n.

Drymaria viscosa S. Watson, Pr. UC: TSB s/n. 


\section{CELASTRACEAE}

Maythenus phyllanthoides Benth. [Tricerma p.], Sh. BCMEX: JPR 2796, HCIB: JJPN 536, JLLL 539, 11256, s/n, s/n, MDL 4489, 4596, 4743, 4837, s/n, RDC 3503, 3517, 3642, 3662, 3690, 3722, 3730, 3786, TFD 6808, SD: PJM 843, 848, RMB 2124, 2134, 2148, RVM 4184, UC: TSB s/n. Mangle dulce.

CHENOPODIACEAE

Allenrolfea occidentalis (S. Watson) Kuntze, Sc. BCMEX: RPR 4, HCIB: AMN 2011-231, JJPN 542, JLLL 556, 1321, 11244, 11250, MDL 4671, 4742, RDC 3687, 3783, SD: RMB 2138, UC: TSB s/n. Saladilla.

Arthrocnemum subterminale (Parish) Standl. [Salicornia subterminalis], Sc. HCIB: AMN 2011-236, JLLL 1400, RDC 3781, SD: JJPN 603, PJM 850, UC: TSB s/n.

Atriplex barclayana (Benth.) D. Dietr. subsp. barclayana, Ph. HCIB: AMN 2011-359, 2012-034, JLLL 1233, 1511, 11376, RDC 3834, 3970, SD: PJM 831.

Atriplex barclayana (Benth.) D. Dietr. subsp. lurida (Brandegee) H.M. Hall et Clem., Ph. HCIB: AMN 2011-370, MDL 4578.

Atriplex barclayana (Benth.) D. Dietr. subsp. sonorae (Standl.) H.M.Hall and Clem., Sh. HCIB: RDC 3685, 3914, 3490a.

Atriplex canescens (Pursh) Nutt. var. canescens, Ph. HCIB: JLLL 11191, MDL 4492, RDC 3771. Costilla de vaca.

Atriplex canescens var. laciniata Parish. Ph. HCIB: JLLL 1319, 11291, RDC 3643.

Atriplex frankenioides Moran, Ph. SD: PJM 842.

Atriplex julacea S. Watson, Ph. HCIB: MDL 4425.

Atriplex leucophylla (Mocq.) D. Dietr. Ph. HCIB: AMN $2011-$ 260, MDL 4814, 4815.

Atriplex linearis S. Watson, Ph. HCIB: JLLL 565, 1312, 11282, 11292, MDL 4766, 4811, RDC 3123, 3581, 3611.

Atriplex magdalenae Brandegee, Ph. HCIB: AMN 2012-161, JLLL 11500, MDL 4668, RDC 3490, 3599, 3658, 3694, 3713, 3729, 3752, UC: TSB s/n.

Atriplex polycarpa (Torr.) S. Watson, Ph. HCIB: JLLL 2006-07.

*Chenopodium murale L., An. HCIB: JLLL 536, 1201, 1326, UC: TSB s/n.

Salicornia bigelovii Torr., Sc. SD: PJM 853.

Salicornia depressa Standl., Sc. HCIB: JLLL 1401.

Salicornia rubra A. Nelson., Sc. HCIB: AMN 2011-201, 2011207, 2011-233, 2011-257, RDC 3507.

Sarcocornia pacifica (Standl.) A.J. Scott. [Salicornia p.], Sc. HCIB: JLLL 1506, RDC 3679, 3691, 3788, SD: PJM 837, 849.

Suaeda californica S. Watson, Sc. HCIB: JJPN 578, JLLL 548.

Suaeda esteroa Ferren et S.A. Whitmore, Sc. HCIB: AMN 2011 237, JLLL 1402, 1501, RDC 3502, 3682, 3692, 3787.

Suaeda fruticosa Forssk. ex J.F. Gmel., Sc. BCMEX: RPR 5, HCIB: JJPN 468, 545, MDL 4429, 4672.

Suaeda moquini (Torr.) Greene, Sc. HCIB: RDC 3127.
Suaeda ramosissima (Standl.) I.M. Johnst., Sc. HCIB: JLLL 1305, 1327, 1440, MDL 4820, SD: JHR 885, UC: TSB s/n. COMBRETACEAE

Laguncularia racemosa (L.) C.F. Gaertn. Hf. HCIB: AMN 2011-176, 2011-185, 2011-196, 2011-203, 2011-209, 2011-244, JJPN 570, JLLL 535, 1502, MDL 4595, 4744, 4829, RDC 3684, 3698, 3778, SD: PJM 854, RMB 2129. Mangle blanco.

CONVOLVULACEAE

*Convolvulus arvensis L., Ph. HCIB: JLLL 2006-06.

Cressa truxillensis Kunth, Ph. HCIB: JJPN 503, MDL 4431, SD: PJM 847, UC: TSB s/n

Ipomoea barbatisepala A. Gray, Vi. HCIB: AMN 2012-174.

Ipomoea hederacea Jacq., Vi. HCIB: JLLL 526, JLLL 1243, RDC 3141.

Ipomoea hirsutula Jacq., Vi. HCIB: JLLL 583.

Ipomoea jicama Brandegee, Ph. HCIB: AMN 2011-345, JLLL 568, 1518, MDL 4441, 4486, 4618, RDC 3232, 3567, 3598, 3652, 3718, 3770, 3831, 3912, UC: TSB s/n. Jícama.

Ipomoea triloba L., Vi. HCIB: JLLL 584.

Jacquemontia abutiloides Benth., Pr. HCIB: AMN 2011-331, 2012-023, JLLL 1340, 1420, 11504, SD: GLW 19578, JPR 4772, RVM 10823, UC: TSB s/n.

Jacquemontia eastwoodiana I.M. Johnst., Pr. HCIB: RDC 3832.

CRASSULACEAE

Crassula connata (Ruiz et Pav.) A. Berger. [Tillaea c.], Sc. UC: TSB s/n.

Dudleya albiflora Rose, Sc. HCIB: JLLL 11367, SD: JPR 2791, RMB 2125, RVM 4177, 10812.

Dudleya rubens (Brandegee) Britton et Rose, Sc. HCIB: JLLL 1359. Siempreviva.

CUCURBITACEAE

Brandegea bigelovii (S. Watson) Cogn., Vi. HCIB: JLLL 484, 1209, RDC 3356, 3509, 3533, SD: JHT 8406.

Cucumis dipsaceus Ehrenb., Vi. HCIB: JLLL 1231.

Echinopepon minimus (Kellogg) S. Watson, Vi. HCIB: AMN 2011-348, RDC 3125, 3266, SD: JPR 4792, 4821, UC: TSB s/n.

Ibervillea sonorae (S. Watson) Greene Ph. HCIB: AMN 2012075. Guereque, Melón de coyote.

Ibervillea sonorae var. peninsularis (I.M. Johnst.) Wigg. Vi. HCIB: JLLL 1331, 11240, MDL 4464, RDC 3716, 3809, 3844, UC: TSB s/n. Guereque, Melón de coyote.

Vaseyanthus brandegeei (Cogn.) Rose, Vi. HCIB: AMN 2011267, JLLL 1526, MDL 4838.

CUSCUTACEAE

Cuscuta corymbosa Ruiz etd Pav., Pa. HCIB: RDC 3250, 3896, UC: TSB s/n.

Cuscuta pentagona Engelm., Pa. HCIB: JLLL 11266, MDL 2840 . 


\section{ELATINACEAE}

Bergia texana (Hook.) Seub.ex Walp., Hf. HCIB: JLLL 1263. EUPHORBIACEAE

Acalypha californica Benth., Sh. HCIB: JLLL 1349, MDL 4626, 4664, RDC 3299, 3819, RVM 10819 SD, UC: TSB s/n. Hierba del cancer.

Acalypha comonduana Millsp. Sh. HCIB: JLLL 11393, 11474, SD: JPR 4791.

Croton californicus Müll.- Arg., Sh. HCIB: AMN 2011-171, 2011-221, 2011-245, 2011-268, JLLL 1409, 11385, MDL 4832, RDC 3154, 3538, 3580, SD: JJPN 580, JLLL 3389, UC: TSB s/n.

Croton ciliatoglandulifer Ortega, Sh. UC: TSB s/n.

Croton magdalenae Millsp., Sh. HCIB: AMN 2011-360, SD: JPR 4795, JPR 4820, UC: TSB s/n

Ditaxis lanceolata (Benth.) Pax et K.Hoffm. [Argythamnia I.], Ph. HCIB: AMN 2011-246, 2011-333, JLLL 11516, RDC 3271 .

Ditaxis neomexicana (Müll.- Arg.) A.Heller [Argythamnia gracilis], Ph. HCIB: MDL 4531.

Ditaxis serrata (Torr.) A. Heller [Argythamnia s.], Ph. HCIB: RDC 3899, UC: TSB s/n.

Ditaxis serrata (Torr.) var. californica (Brandegee) V.W. Steinm. et Felger [Argythamnia C.], Ph. HCIB: JLLL 1412, 1520, MDL 4564, RDC 3279, 3484, 3774, SD: GLW 19583.

Euphorbia albomarginata Torr. et A. Gray, [Chamaesyce a.], Pr. HCIB: JLLL 11390, MDL 4835, RDC 3900, 3971, SD: RDC 1801.

Euphorbia arizonica Engelm. [Chamaesyce a.], Pr. HCIB: MDL 4725, RDC 3842. Golondrina.

Euphorbia bartolomaei Greene [Chamaesyce b.], Pr. HCIB: MDL 4507. Golondrina.

Euphorbia brandegeei Millsp. [Chamaesyce b.], Pr. HCIB: JLLL 1395, RDC 3496, UC: TSB s/n, TSB s/n. Golondrina.

Euphorbia californica Benth. Liga, Sh. HCIB: JLLL 11203, 11225, 11274, 11298, MDL 4482, RDC 3208, 3613, 3629, 3674, 3708, 3757, SD: RMB 2137. Liga.

Euphorbia ceroderma I.M. Johnst., Sh. HCIB: JLLL 6242, MDL 4457, RDC 3588, 3625, 3656, SD: RVM 21364. Espadín.

Euphorbia dentosa I.M. Johnst. [Chamaesyce d.], Ph. HCIB: MDL 4554.

Euphorbia eriantha Benth., An. HCIB: JLLL 523, 532, 11219, 11241, 11382, MDL 4587, 4747, RDC 3227, 3495, 3574, 3772, 3840, UC: TSB s/n.

Euphorbia hindsiana Benth., Sc. UC: TSB s/n.

Euphorbia hyssopifolia L. [Chamaesyce h.], Ph. HCIB: JLLL 576. Golondrina.

Euphorbia lomelii V.W.Steinm. Sc: HCIB: JLLL 1248, 1423, 11206, 11237, 11273, 11296, 11529, MDL 4460, s/n, RDC 3235, 3562, 3600, 647, 3677, 3707, 3726, 3758, SD: RMB 2110, 2153, RVM 10821, UC: TSB s/n. Candelilla.
Euphorbia maculata L. [Chamaesyce m.], Pr. HCIB: RDC 3180. Golondrina.

Euphorbia magdalenae Benth., Sh. HCIB: AMN 2011-355, JLLL 1419, JPR 4820b, RDC 3826, 3911, SD: CD 2041, RMB 2105, 2163, UC: TSB s/n.

Euphorbia micromera Boiss. [Chamaesyce m.], Pr. HCIB: JJPN 579, MDL 4490, 4550, RDC 3215, 3244, 3573, 3668, 3719. Golondrina.

Euphorbia misera Benth. Sc: HCIB: AMN 2011-363, JLLL 1313, 1399, RDC 3251, 3610, 3767, 3824, SD: RMB 2117.

Euphorbia pediculifera Engelm. [Chamaesyce p.], Ph. UC: TSB $\mathrm{s} / \mathrm{n}$. Golondrina.

Euphorbia polycarpa Benth. [Chamaesyce p.], Pr. HCIB: AMN 2011-346, 2012-028, 2012-035, 2012-172, 2012-175, JLLL 1229, 1347, 1497, MDL 4417, 4585, RDC 3173, 3335, 3337, UC: TSB s/n. Golondrina.

Euphorbia pondii Millsp. [Chamaesyce p.], Pr. HCIB: JJPN 506, JLLL 1480.

Euphorbia pumicicola Huft, Pr. HCIB: RDC 3922.

Euphorbia serpens Kunth. [Chamaesyce s.], Pr. HCIB: AMN 2011-177, 2011-204, 2011-223, JLLL 1271, MDL 4607, UC: TSB s/n. Golondrina.

Euphorbia serpyllifolia Pers. [Chamaesyce s.], Pr. HCIB: JLLL 11261, SD: JHT 8399. Golondrina.

Euphorbia setiloba Engelm. ex Torr., Pr. HCIB: JLLL 1425, 11475.

Euphorbia tomentulosa S. Watson, An. HCIB: AMN 2012157.

Jatropha canescens (Benth.) Müell.-Arg. Sc: HCIB: AMN 2012079, 2012-080, 2012-081, JLLL 1436, RDC 3285, 3304, 3814, SD: CD 2045, JPR 4809, RMB 2114. Lomboi.

Jatropha cinerea (Ortega) Müell.-Arg. Sc: HCIB: JLLL 518, 7671, 11197, 11224, 11271, 11293, 11395, MDL 4458, 4556, RDC 3549, 3591, 3702, 3732, 3751, s/n, UC: TSB $\mathrm{s} / \mathrm{n}$. Lomboi.

Jatropha cuneata Wiggins et Rollins, Sc. HCIB: AMN 2011337, JLLL 11525, RDC 358, 3640. Matacora.

Phyllanthus brandegeei Millsp., Ph. HCIB: MDL 2612.

Phyllanthus evanescens Brandegee, Ph. HCIB: JLLL 582.

*Ricinus communis L. Sh. HCIB: RDC 3130, 3526. Higuerilla.

Stillingia linearifolia S. Watson, An. HCIB: JLLL 1212.

FABACEAE

Acacia farnesiana (L.) Willd., Sh. HCIB: JLLL 1364, 1514, 2006-04, 7759b, RDC s/n, SD: RDC 1809. Vinorama.

Acacia peninsularis (Britton et Rose) Standl., Tr. HCIB: JLLL 6243, MDL 4654. Teso.

Acaciella goldmanii Britton et Rose [Acacia g.], Sh. HCIB: JLLL 11313.

Astragalus hornii A. Gray var. minutiflorus M.E. Jones, Ph. HCIB: MDL 4631. 
Astragalus magdalenae Greene, Ph. HCIB: AMN 2012-026, JLLL 11378, SD: RMB 2156b, RVM 3541, UC: TSB s/n.

Caesalpinia pannosa Brandegee, Sh. HCIB: AMN 2012-155, JLLL 1394, 1522, MDL 4448, 4483, 4567, 4663, 4836, RDC 3209, 3571. Palo estaca.

Calliandra californica Benth. Sh. HCIB: AMN 2011-356, JLLL 1427, 11481, MDL 4627, RDC 3255, 3300, 3351, SD: JPR 4824, RMB 2107, UC: TSB s/n. Tabardillo.

Calliandra eriophylla Benth. Sh. HCIB: AMN 2011-352, JLLL 1304, RDC 3818, 3255b.

Dalea brandegeei (Rose) Bullock, Ph. HCIB: AMN 2011-339, JLLL 1339, 11479, 11515, MDL 4611, SD: GLW 19587, JPR 4765, 4807, 4811, RVM 3538, 10813, UC: TSB s/n.

Dalea mollis Benth., An. HCIB: MDL 4537, RDC 3219, 3973.

Desmanthus covillei (Britton et Rose) Wiggins, Sh. HCIB: JLLL 585, 7754b.

Desmanthus fruticosus Rose, Sh. HCIB: AMN 2011-351, 2012019, JLLL 11491, RDC 3260, SD: RMB 2112.

Ebenopsis confinis (Standl.) Barneby et J.W. Grimes [Pithecellobium confine], Sh. HCIB: JLLL 1411, 11242, s/n, RDC 3347, 3514. Ejotón.

Errazurizia benthami (Brandegee) I.M. Johnst., An. UC: TSB s/n. Lotus bryantii (Brandegee) Ottley, An. HCIB: AMN 2011-186, JJPN 502, 587, JLLL 1407, MDL 4834, UC: TSB s/n.

Lupinus arizonicus (S. Watson) S. Watson, An. HCIB: MDL 4621, SD: JPR 4777, UC: TSB s/n. Alfalfilla.

Lupinus sparsiflorus var. insignitus. An. UC: TSB s/n. Alfalfilla.

Marina divaricata (Benth.) Barneby [Dalea d.], Ph. HCIB: AMN 2012-021, RDC 3287, SD: GLW 19588, JPR 4784, RMB 2162, UC: TSB s/n.

Marina evanescens (Brandegee) Barneby [Dalea e.], An. HCIB: RDC 3176.

Marina parryi (Torr. et A. Gray) Barneby [Dalea p.], An. HCIB: JJPN 1308, JLLL 566, 1244, 1251, 1344, RDC 3214, UC: TSB s/n.

Marina peninsularis (Rose) Barneby [Dalea p.], Ph. HCIB: JLLL 510, 564, 1264, 1311, MDL 4536, RDC 3146, 3218, 3607, 3738.

Mimosa margaritae Rose, Sh. HCIB: JLLL 11471, UC: TSB s/n.

Mimosa purpurascens B.L. Robinson [M. distachya], Sh. HCIB: MDL 1582.

Olneya tesota A. Gay, Tr. HCIB: JLLL 11205, 11312. Teso.

*Parkinsonia aculeata L., Sh. HCIB: JLLL 11257, RDC 3489. Junco.

Parkinsonia florida (Benth. ex A. Gray) S. Watson, [Cercidium floridum], Tr. HCIB: JLLL 1388, 11198, MDL 4652, RDC 3777, 3359. Palo verde.

Parkinsonia praecox (Ruiz et Pav. ex Hook.) Hawkins, [Cercidium p.], Sh. BCMEX: JPR 2803, HCIB: JLLL 1388, 11198, RDC 3359. Palo brea.

Phaseolus filiformis Benth., Vi. HCIB: AMN 2011-172, $2011-$
178, 2011-197, 2012-032, JJPN 504, 564, JLLL 1276, 11234, 11396, 11502, MDL 4413, 4499, 4606b, RDC 3237, 3918, SD: PJM 835, UC: TSB s/n. Frijolillo.

Prosopis articulata S. Watson, Tr. HCIB: JLLL 11192, 11227, 11267, 11297, MDL 4497, 4597, 4753, s/n, RDC 3516, 3555, 3602, 3641, 3731, 3766, FG 9796 SD. Mezquite amargo.

Prosopis palmeri S. Watson, Tr. HCIB: JLLL 1240, 6244, 11283, MDL s/n. Palo fierro.

Psorothamnus emoryi (A. Gray) Rydb., Ph. HCIB: AMN 2011224, 2011-247, 2011-269, JLLL 1404, 11243, RDC 3220, 3587.

Psorothamnus emoryi A. Gray var. arenarius (Brandegee) Barneby, An. HCIB: AMN 2012-153, JLLL 11389, MDL 4421, 4472, 4568, 4824.

Sesbania herbacea (Mill.) McVaugh, An. HCIB: AMN 2012173, JLLL 580, MDL 2608, RDC 3168.

Vicia ludoviciana Nutt. ex Torr. et A. Gray, An. HCIB: MDL 4604.

\section{FOUQUIERIACEAE}

Fouquieria diguetii (Tiegh.) I.M. Johnst., Sh. HCIB: AMN $2011-$ 248, 2012-004, JLLL 1515, 6139, 11199, 11229, 11277, 11287, 11531, MDL s/n, RDC 3360, 3501, 3556, 3592, 3632, 3657, 3700, s/n, SD: PJM 858, RMB 2113, 2142. Palo Adán.

FRANKENIACEAE

Frankenia palmeri S. Watson, Ph. HCIB: JLLL 550, MDL 4426. GENTIANACEAE

Eustoma exaltatum (L.) Salisb. ex G. Don., An. HCIB: MDL 4769.

\section{GERANIACEAE}

*Erodium cicutarium (L.) L'Hér. ex Aiton, An. UC: TSB s/n. GOODENIACEAE

Scaevola plumieri (L.) Vahl., Sc. HCIB: JLLL s/n.

HYDROPHYLLACEAE

Nama coulteri A. Gray, An. HCIB: MDL 4600, SD: JHT 7942.

Phacelia scariosa Brandegee, An. HCIB: JLLL 1353, SD: JPR 4767, 4819.

\section{KRAMERIACEAE}

Krameria erecta Willd. ex Schult., Ph. HCIB: MDL 4530, RDC 3265, 3289, SD: RMB 2154, RVM 10811. Mezquitillo.

Krameria parvifolia Benth., Ph. HCIB: AMN 2011-319, $2011-$ 354, JLLL 1408, MDL 4825, RDC 3645, 3673, s/n.

Krameria paucifolia (Rose) Rose, Ph. HCIB: JLLL 11207, RDC 3242, 3575, 3635, 3711, 3749.

LAMIACEAE (LABIATAE)

Clinopodium brownei (Sw.) Kuntze [Satureja b.], Vi. HCIB: JLLL 1226.

Hyptis emoryi Torr., Sh. HCIB: JLLL 1429, MDL 4504, RDC 3822. Salvia.

Hyptis emoryi Torr. var. amplifolia I.M. Johnst., Sh. HCIB: MDL 4630, RDC 3278. Salvia 
Hyptis laniflora Benth., Sh. HCIB: RDC 3239, SD: JPR 4798. Salvia

Hyptis tephrodes A. Gray, Sh. HCIB: JLLL 7758b. Salvia

Salvia cedrosensis Greene, Ph. HCIB: AMN 2011-374, 4625. UC: TSB s/n.

Salvia misella Kunth, Ph. HCIB: JLLL 498.

Salvia similis Brandegee, Ph. SD: JPR 4800.

Teucrium glandulosum Kellogg, An. HCIB: JLLL 513, MDL 4634, 4756, RDC 3119, 3779.

LOASACEAE

Eucnide cordata Kellogg, Ph. SD: JPR 4806.

Mentzelia adhaerens Benth., An. HCIB: JLLL 531, 1443, 1508, 11496, MDL 4480, 4544, 4436b, RDC 3234, 3280, 3349, 3510, 3576, SD: JPR 4776, RVM 10829, UC: TSB s/n. Pega ropa.

\section{LORANTHACEAE}

Psittacanthus sonorae (S. Watson) Kuijt, [Phrygilanthus s.], Pa. BCMEX: JPR 1715, HCIB: AMN 2012-148, SD: RMB 2104, UC: TSB s/n. Toji.

LYTHRACEAE

Ammannia coccinea Rottb., Hf. HCIB: JLLL 496, 1227, 1273, MDL 4435.

Lythrum bryantii Brandegee, Hf. HCIB: MDL 2363, 4436, RDC 1804, SD: JRR 7135.

Lythrum californicum Torr. et A. Gray, Hf. HCIB: MDL 4599. Lythrum gracile Benth., Hf. HCIB: JLLL 1272.

MALPIGHIACEAE

Callaeum macropterum (DC.) D.M. Johnson, [Mascagnia macroptera], Vi. HCIB: MDL 4662.

Janusia californica Benth. [J. scandens], Ph. HCIB: JLLL 11486, SD:JPR 4785.

MALVACEAE

Abutilon californicum Benth., Ph. HCIB: JLLL 515, 1228, 11276, 11307, MDL 4444, 4762, RDC 3293, 3603, 3637, 3740, 3764, SD: JPR 4789. Malvilla.

Abutilon dugesii S. Watson, Ph. HCIB: AMN 2012-009, MDL 4642, RDC 3619. Malvilla.

Abutilon palmeri A. Gray, Ph. HCIB: AMN 2011-330, JLLL 567. Malvilla.

Anoda pentaschista A. Gray, Ph. HCIB: MDL 2361, RDC 3167, RDC 3962.

Corchorus hirtus L., An. HCIB: JLLL 561.

Gossypium davidsonii Kellogg, Sh. HCIB: MDL 4662b, RDC 3207, SD: RVM 10809.

Gossypium harknessii Brandegee, Sh. BCMEX: JPR 1716, HCIB: AMN 2011-347, JLLL 1421, 11513, MDL 4610, RDC 3282, SD: CFH 356, JPR 4787, RMB 2102, UC: TSB s/n.

Herissantia crispa (L.) Brizicky, Ph. HCIB: MDL 4471, 4552, RDC 3229, 3357, 3583.

Hibiscus denudatus Benth., Ph. HCIB: JLLL 11506, SD: RVM 10822.
Horsfordia alata (S. Watson) A. Gray, Ph. HCIB: AMN 2011343, JLLL 1428, 11210, 11309, MDL 4561, s/n, RDC 3243, 3263, 3295, 3608, 3739, 3820.

Malva parviflora L., Ph. HCIB: JLLL 547.

Malvastrum coromandelianum (L.) Garcke, Ph. HCIB: JLLL 1206.

Malvella leprosa (Ortega) Kaprov., Ph. HCIB: JLLL 1235, MDL 4462.

Sida xanti A. Gray, An. HCIB: RDC 3963.

Sphaeralcea axillaris S. Watson, An. HCIB: MDL 4473, 4731.

Sphaeralcea coulteri (S. Watson) A. Gray, An. HCIB: MDL 4533, RDC 3129, 3166.

Sphaeralcea coulteri (S. Watson) A. Gray var. californica (Rose) Kearney, An. HCIB: JLLL 11223, RDC 3233, 3346.

Sphaeralcea coulteri (S. Watson) A. Gray var. margaritae (Brandegee) Kearney, An. HCIB: JLLL 1315, MDL 4643, 4607b, RDC 3566, 3646, SD: TT 573.

Sphaeralcea hainesii Brandegee, Ph. HCIB: JLLL 1318, 1368, MDL 4580.

Sphaeralcea orcuttii Rose, Ph. HCIB: MDL 2396.

MOLLUGINACEAE

Glinus radiatus (Ruiz et Pav.) Rohrb., Hf. HCIB: MDL 4647.

Mollugo verticillata L., An. HCIB: JLLL 530, 11507, MDL 4582, 4637.

NYCTAGINACEAE

Abronia gracilis Benth., Ph. HCIB: AMN 2012-160, JLLL 546, 11415, MDL 4452, 4493, 4570, 4669, 4823, UC: TSB s/n. Verbena.

Abronia maritima Nutt. ex S. Watson, Pr. HCIB: AMN 2011173, 2011-179, 2011-187, 2011-225, 2011-228, 2011-270, JLLL 1477, 11251, 11394, SD: RMB 2155, UC: TSB s/n.

Allionia incarnata L., Ph. HCIB: JLLL 522, MDL 4549, RDC 3898, 3974, SD: JLLL 4845, UC: TSB s/n.

Boerhavia coulteri (Hook. f.) S. Watson, An. HCIB: MDL 4487, RDC 3558. Mochito.

Boerhavia erecta L., An. HCIB: AMN 2011-349, JLLL 9373, 11495, RDC 3230, 3902, UC: TSB s/n.

Boerhavia intermedia M.E. Jones, An. HCIB: AMN 2012-166, JLLL 529, MDL 2848, RDC 3160; SD: JHT 7943.

Boerhavia spicata Choisy, An. HCIB: RDC 3968.

Boerhavia xanti S. Watson, An. HCIB: JLLL 11414.

Commicarpus brandegeei Standl., Ph. SD: JPR 4823.

Commicarpus scandens (L.) Standl., Vi. HCIB: JLLL 1369, MDL 4558, RDC 3223.

Mirabilis laevis (Benth.) Curran, Ph. HCIB: AMN 2011-324, 2012-008, JLLL 1350, SD: JPR 4799, RVM 3530, UC: TSB $\mathrm{s} / \mathrm{n}$.

\section{OLACACEAE}

Schoepfia californica Brandegee, Ph. BCMEX: JPR 2797, HCIB: JLLL 1329, MDL 4617, RDC 3252, 3302, SD: JPR 4773, RMB 2100, RMB 2165, RVM 10810, 10830, UC: TSB s/n. 


\section{ONAGRACEAE}

Camissonia crassifolia (Greene) P.H. Raven, An. HCIB: AMN 2012-024, 2012-152, JJPN 556, 584, 604, JLLL 11380, UC: TSB s/n

Camissonia sceptrostigma (Brandegee) P.H. Raven, An. HCIB: JPR 7755, RDC 914, 3841, SD: TT 568.

Gongylocarpus fruticulosus (Benth.) Brandegee subsp. fruticulosus, Sh. HCIB: AMN 2012-012, 2012-077, SD: CD 2034, RVM SD, RVM 10804.

Gongylocarpus fruticulosus (Benth.) Brandegee subsp. glaber (J.H. Thomas) Carlquist et P.H. Raven, Sh. BCMEX: JPR 1719, HCIB: RDC 3823, 3921.

Lopezia clavata Brandegee, Hf. HCIB: JLLL 500, RDC 3626.

Ludwigia octovalvis (Jacq.) P.H. Raven, Hf. HCIB: RDC 3152.

Oenothera flava (A. Nelson) Garrett, Ph. HCIB: MDL 2607.

Oenothera kunthiana (Spach) Munz, Ph. HCIB: JLLL 1222.

OXALIDACEAE

Oxalis latifolia Kunth, Ph. HCIB: AMN 2011-322, 2011-366. Agrito.

PAPAVERACEAE

Argemone gracilenta Greene, An. HCIB: JLLL 8144, RDC 3338, RDC 3527. Cardo.

PASSIFLORACEAE

Passiflora arida (Mast. and Rose) Killip, Vi. HCIB: JLLL 559, SD: JHT 8405. Granadilla.

Passiflora foetida L. var. longipedunculata Killip, Vi. HCIB: RDC 3821. Granadilla.

Passiflora fruticosa Killip, Vi. BCMEX: JPR 2795, HCIB: AMN 2011-368, JLLL 1342, 11411, MDL 4614, SD: JPR 1721, JPR 4803. Granadilla.

PEDALIACEAE (MARTYNIACEAE)

Proboscidea altheifolia (Benth.) Decne, An., HCIB: AMN 2011-249, 2011-327,2012-078, JLLL 11235, 11384, MDL 4445, 4502, 4569, RDC 3561, 3634, 3721, 3745, UC: TSB $\mathrm{s} / \mathrm{n}$. Espuela del diablo.

PHYTOLACCACEAE

Stegnosperma halimifolium Benth., Sh. BCMEX: JPR 1710, HCIB: AMN 2011-369, JLLL 1410, 1528, MDL 4665, RDC 3196, 3269, SD: RMB 2108. Amole.

PLANTAGINACEAE

Plantago insularis Eastw. var. fastigiata (E. Morris) Jeps., An. HCIB: JLLL 1355, RDC 3138.

Plantago ovata Forssk., An. SD: JPR 4813.

POLYGALACEAE

Polygala magdalenae Brandegee, An. HCIB: JLLL s/n, 11859.

Polygala xanti A. Gray, An. HCIB: AMN 2011-325, JLLL 11480, UC: TSB s/n.

POLYGONACEAE

Eriogonum trichopes Torr., An. HCIB: RDC 3217.

Harfordia macroptera (Benth.) Greene et Parry, Sh. HCIB: RDC 3909, UC: TSB s/n.
* Rumex californicus Rech. f., An. HCIB: MDL 4603.

Rumex conglomeratus Murray, An. HCIB: JLLL 1275, 1367.

Rumex inconspicuus Rech. f., An. HCIB: JLLL 11263, MDL 4605.

PORTULACACEAE

Portulaca californica D. Legrand, Sc. SD: PJM 838.

*Portulaca halimoides L., Sc. HCIB: JLLL 1392. Verdolaga.

Talinum paniculatum (Jacq.) Gaertn. Hp. HCIB: RDC 2853.

PRIMULACEAE

Samolus ebracteatus Kunth, Ph. HCIB: MDL 4773.

RANUNCULACEAE

Clematis drummondi Torr. et A. Gray, Vi. HCIB: JLLL 1204.

Clematis pauciflora Nutt., Vi. HCIB: MDL 4646.

RESEDACEAE

*Oligomeris linifolia (Vahl) J.F. Macbr., An. HCIB: AMN 2011170, JLLL 1348, SD: JPR 4812, UC: TSB s/n.

RHAMNACEAE

Colubrina glabra S. Watson, Sh. HCIB: JLLL 1431, UC: TSB s/n. Palo Colorado.

Condalia globosa I.M. Johnst. Sh. HCIB: JLLL s/n, RDC 3761. Palo negrito.

Ziziphus obtusifolia (Hook. ex Torr. et A. Gray) A. Gray, Sh. HCIB: RDC 3747. Alfilerillo.

RHIZOPHORACEAE

Rhizophora mangle L. Hf. HCIB: AMN 2011-181, 2011-213, 2011-254, JJPN 568, JLLL 545, 1218, 1504, 11253, MDL 4594, 4746, SD: JPR 4781, RMB 2139, UC: TSB s/n. Mangle rojo.

RUBIACEAE

Hedyotis brevipes (Rose) W.H. Lewis [Houstonia b.], Hp. HCIB RDC 2674.

Stenotis mucronata (Benth.) Terrell. [Houstonia m.], Ph. HCIB: JLLL 11838.

SALICACEAE

Salix bonplandiana Kunth. Hf. HCIB: JLLL 1219, 1337, 1362. Sauce.

SAPINDACEAE

Cardiospermum corindum L. Vi. HCIB: JLLL 525, 541, 11214, JPR 4834, MDL 4565, 4758, RDC 3194, 3480, 3559, 3650. Tronadora.

Cardiospermum tortuosum Benth., Sh. HCIB: AMN 2011-323, JLLL 1433, 11477, RDC 3272, 3816, SD: GLW 19575, JPR 4793, RVM 10820, UC: TSB s/n.

SCROPHULARIACEAE

Antirrhinum cyathiferum Benth., An. HCIB: MDL 4615, RDC 3897, SD: JPR 4780, UC: TSB s/n

Antirrhinum kingii S. Watson var. watsonii (Vasey et Rose) Munz, An. HCIB: JLLL 11501, UC: TSB s/n.

Antirrhinum nuttallianum Benth., An. HCIB: AMN 2012-010, MDL 4514.

Galvezia juncea (Benth.) A. Gray, Sh. HCIB: RDC 3903. 
Galvezia juncea (Benth.) var. pubescens I.M. Johnst., Ph. HCIB: AMN 2012-007, SD: JPR 4818.

Mecardonia exilis (Brandegee) Pennel, An. HCIB: MDL 2366, RDC 1807.

Mecardonia vandellioides (Kunth) Pennell, Hf. HCIB: MDL 4467, 4635.

Mimulus pilosus (Benth.) S. Watson, Hf. HCIB: JLLL 489.

Stemodia durantifolia (L.) Sw., An. HCIB: JLLL 474, RDC 3144.

SIMAROUBACEAE

Castela peninsularis Rose, Sh. BCMEX: JPR 1709, JPR 2793, HCIB: JLLL 1430, 11279, 11409, SD: RMB 2145. Palo negrito.

\section{SIMMONDSIACEAE}

Simmondsia chinensis (Link) C.K. Schneid. Sh. HCIB: AMN 2011-255, 2011-361, 2012-003, JLLL 538, 1507, MDL 4449, 4583, 4621b, RDC 3277, 3294, 3485, 3518, 3630, 3655, 3705, SD: JPR 4808, RMB 2111, 2150. Jojoba.

SOLANACEAE

Datura discolor Benth., An. HCIB: JLLL 506, 1213, 11306, MDL 4442, RDC 3222, 3284, 3570, 3595, 3714, 3775, UC: TSB s/n. Toloache.

Lycium andersonii A. Gray var. deserticola (C.L. Hitchc.) Jeps., Sh. HCIB: JLLL 1519, MDL 4498, 4529, 4560, 4655, s/n, RDC 3197, 3303, 3333, 3487, 35193500, 3541, 3563, 3695, 3703, 3724. Frutilla.

Lycium berlandieri Dunal var. peninsulare C.L. Hitchc., Sh. HCIB: AMN 2011-334, MDL 4463, RDC 3660, 3812. Frutilla.

Lycium brevipes Benth., Sh. HCIB: AMN 2011-183, 2011-191, 2011-199, 2011-206, 2011-215, 2011-226, 2011-256, 2011273, 2012-017, JJPN 551, 572, JLLL 1322, 1363, 1370, 11255, 11388, 11517, MDL 4443, 4501, RDC 3124. Frutilla.

Lycium californicum A. Gray, Sh. HCIB: JLLL 1309. Frutilla.

Lycium carolinianum Walter. Sh. HCIB: JLLL 1310. Frutilla.

Lycium fremontii A. Gray var. congestum C.L. Hitchc., Frutilla. Sh. HCIB: AMN 2011-338, 2012-011, JLLL 1217, 1521, MDL 4732, 4822, RDC 3486, 3542, TFD 6810, SD: FG 9795. Frutilla.

Lycium megacarpum Wigg. Sh. HCIB: JLLL 586, 11392, RDC 3916. Frutilla.

Nicotiana clevelandii A. Gray, An. HCIB: RDC 3131, UC: TSB $\mathrm{s} / \mathrm{n}$.

Nicotiana glauca Graham, Ph. HCIB: MDL 4821, RDC 3537. Tabaquillo.

Nicotiana trigonophylla Dunal, An. HCIB: JLLL 1372, RDC 3524, SD: JPR 4822.

Petunia parviflora Juss., Hf. HCIB: JLLL 475, 1274, RDC 3158.

Physalis acutifolia (Miers) Sandwith, An. HCIB: AMN 2012167, JLLL 1268, RDC 3164.
Physalis angulata L., An. HCIB: RDC 3137.

Physalis crassifolia Benth., An. HCIB: AMN 2012-083, JJPN 505, JLLL 499, 503, MDL 4419, 4437, RDC 3231, 3353, 3498, SD: JPR 4816

Physalis crassifolia var. infundibularis I.M. Johnst., Ph. HCIB: AMN 2012-033, JLLL 11387, MDL 4456, 4506, 4551, s/n, SD: PJM 832.

Physalis glabra Benth., An. HCIB: JLLL 1405, UC: TSB s/n.

Physalis pubescens L., An. HCIB: JLLL 1232.

Solanum americanum Mill., An. HCIB: MDL 4602, RDC 3156, 3532.

Solanum furcatum Dunal, An. HCIB: JLLL 476.

Solanum hindsianum Benth., Sh. HCIB: JLLL 512, 11209, 11233, 11275, 11527, MDL 4478, 4526, RDC 3195, 3268, 3483, 3550, 3620, 3648, 3666, 3712, 3735, 3827, SD: JPR 4810. Mariola.

STERCULIACEAE (part as MALVACEAE)

Ayenia compacta Rose, Ph. UC: TSB s/n.

Ayenia pusilla L., An. UC: TSB s/n.

Melochia tomentosa L., Sh. HCIB: AMN 2011-350, JLLL 1216, 1417, 11216, 11478, 11514, RDC 3274, 3817, UC: TSB s/n. Malvarosa.

TAMARICACEAE

*Tamarix aphylla (L.) H. Karst., Tr. HCIB: AMN 2012-025. Pino salado.

URTICACEAE

Parietaria floridana Nutt., An. HCIB: JLLL 1202.

Parietaria hespera B.D. Hinton, An. SD: JPR 4796.

VERBENACEAE

Avicennia germinans (L.) L. Hf. HCIB: AMN 2011-192, $2011-$ 229, JJPN 569, JLLL 1503, 11254, 11398, 7756b, MDL 4590, 4745, 4827, SD: CD 2046, PJM 836, 851, RMB 2131, UC: TSB s/n. mangle salado.

Burroughsia fastigiata (Brandegee) Moldenke, Ph. HCIB: JLLL 1270, 11260, MDL 2367, 3856, 4755, RDC 1802, 3175, 3341 .

Citharexylum flabellifolium S. Watson, Sh. HCIB: JLLL 1245, MDL 2369a.

Lippia palmeri S. Watson, Sh. HCIB: JLLL 11482, RDC 3270, 3815, SD: JPR 4766, UC: TSB s/n. Oregano.

Verbena gooddingii Briq., Ph. HCIB: RDC 3720.

Verbena menthifolia Benth., An. HCIB: JLLL 1203, MDL 4656.

Verbena orcuttiana L.M. Perry, An. HCIB: JLLL 497.

Verbena perennis Wooton, Ph. HCIB: RDC 1136, 3540.

VIOLACEAE

Hybanthus verticillatus (Ortega) Baill., An. UC: TSB s/n.

VISCACEAE

Phoradendron brachystachyum (DC.) Nutt. [P. diguetianum], Pa. HCIB: JLLL 1424, 11412, RDC 3810. Toji.

Phoradendron californicum Nutt., Pa. UC: TSB s/n. Toji. 


\section{ZYGOPHYLLACEAE}

Fagonia barclayana (Benth.) Rydb., Ph. HCIB: MDL 4510.

Fagonia californica Benth., Ph. HCIB: AMN 2011-320, 2011344, JLLL 1253, MDL 4640, RDC 3906, SD: CD 2036, RVM 10816.

Fagonia laevis Standl., Ph. HCIB: JJPN 1310.

Fagonia villosa D.M. Porter, Ph. HCIB: JLLL 517, 571, 1334, 11494.

Kallstroemia californica (S. Watson) Vail., An. HCIB: MDL 4562. Pelagallina.

Kallstroemia peninsularis D.M. Porter, An. HCIB: AMN 2012156, JJPN 510, JLLL 519. Pelagallina.

Larrea tridentata (Sessé et Moc. ex DC.) Coville, Sh. HCIB: JLLL 524, 11217, 11286, 11311, MDL 4476, RDC 3622, 3644, UC: TSB s/n. Gobernadora.

*Tribulus cistoides L., Cuernito. An. HCIB: JLLL 533.

Viscainoa geniculata (Kellogg) Greene var. pinnata D.M. Porter, Sh. HCIB: JLLL 1414, 1509, RDC 3201. Guayacán.

Monocotiledons

ALOACEAE (XANTHORRHOEACEAE)

*Aloe vera (L.) Burm. f., Sc. HCIB: JLLL 1513. Sábila.

ASPARAGACEAE (AGAVACEAE, inc. LILIACEAE)

Agave margaritae Brandegee, Sc. HCIB: AMN 2012-001, JLLL 11375, SD: JPR 2833, RMB 2109, 2833, UC: TSB s/n. Mezcalillo.

Triteleiopsis palmeri (S. Watson) Hoover, Ph. HCIB: MDL 4433, RDC 3149, 3838.

Yucca valida Brandegee, Sc. HCIB: RDC 3590, 3672, 3741, 3765. Datilillo.

Zephyranthes arenicola Brandegee, Ph. HCIB: MDL 4174b, UC: TSB s/n.

BROMELIACEAE

Tillandsia recurvata (L.) L., Ep. HCIB: JLLL 11211, 11284, MDL 735, 2389, 4534, RDC 3355, SD: RVM 21337. Gallito.

CYPERACEAE

Cyperus dioicus I.M. Johnst., An. SD: JPR 1717.

Cyperus esculentus L., Hf. HCIB: AMN 2012-169, JLLL 562, 1259, RDC 3143, 3147, 3181, 3535.

Cyperus odoratus L., Ph. HCIB: RDC 3153b.

Cyperus perennis (M.E. Jones) O’Neill, Hf. HCIB: JLLL 1260.

Eleocharis geniculata (L.) Roem. et Schult., Hf. HCIB: RDC 3153.

Schoenoplectus saximontanus (Fern.) J. Raynal, Hf. HCIB: MDL 4606.

JUNCACEAE

Juncus acutus L., Sh. HCIB: RDC 3148. Tulillo.

POACEAE (GRAMINAE)

Anthephora hermaphrodita (L.) Kuntze, An. HCIB: AMN 2011335, MDL 4438.

Aristida californica Thurb. var. glabrata (Vasey) Hitchc., Ph.
HCIB: AMN 2011-250, 2011-271, JLLL 1413, 11238, 11487, MDL 4447, 4586, RDC 3494, 3577, 3636, UC: TSB s/n.

*Aristida heymannii Regel [A. adscensionis s.I.], An. HCIB: JLLL 1351, 4830, 11509; MDL 4470, SD: JRR 7140. Zacate aceitilla.

Bouteloua barbata Lag., An. HCIB: JLLL 549, MDL 4488, 4547, 4581, RDC 3245, 3913, 3964, SD: JPR 4779, PJM 844, TT 567. Zacate banderita.

Bouteloua parryi (E. Fourn.) Griffiths, An. HCIB: AMN 2011202, 2011-208, UC: TSB s/n.

*Cenchrus echinatus L. [C. incertus, C. spinifex], An. HCIB: AMN 2012-150; JLLL 494, 544, 11222; MDL 3855, 4454, 4509; RDC 3116, 3210, 3493, 3609; SD: JPR 7754. Huizapol.

Cenchrus palmeri Vasey, An. HCIB: AMN 2011-251, 2011272, JLLL 11215, 11280, 11301, 11508, MDL 4503, 4532, RDC 3136, 3539, 3548, 3564, 3597, 3633, 3671, 3704, 3736, 3760, s/n. Huizapol.

Chloris brandegei (Vasey) Swallen [Enteropogon b., Leptochloa b.], An. UC: TSB s/n.

Chloris virgata Sw. An. HCIB: AMN 2012-162, JLLL 486, 521, MDL 2838, 4412, RDC 3118, 3170, 3966, UC: TSB s/n.

*Cynodon dactylon (L.) Pers. Ph. HCIB: JLLL 485, RDC 3135 , 3536. Zacate Bermuda.

*Dactyloctenium aegyptium (L.) Willd., An. HCIB: MDL 4411, RDC 3117.

Digitaria californica (Benth.) Henrard, Ph. HCIB: JLLL 11817.

Digitaria horizontalis Willd. [Syntherisma digitatum], An. HCIB: JLLL 563.

Digitaria insularis (L. ) Fedde., Ph. HCIB: JLLL 554, 555, 1307, 1320, 1376, 1377, 1512, 1523, 11503, MDL 4573, 4574, 4633, RDC 3297, 3813, SD: PJM 834, RMB 2123, 2143, RVM 10817, UC: TSB s/n.

Distichlis spicata (L.) Greene, Ph. HCIB: JLLL 1450, RDC s/n, SD: RMB 2132.

Echinochloa colona (L.) Link, An. HCIB: JLLL 479, 572, 1223, 1267, MDL 4468, SD: JHT 7947.

Enneapogon desvauxii P. Beauv., Ph. HCIB: AMN 2011-220, SD: JLLL 4843.

Eragrostis amabilis (L.) Wight et Arn. [E. tenella], An. HCIB: RDC 3965.

Eragrostis cilianensis (All.) Vignolo ex Janch., An. HCIB: JLLL 488, MDL 4542.

Eragrostis pectinacea (Michx.) Nees, An. HCIB: JLLL 478, 11294, RDC 3174.

Eriochloa acuminata (J. Presl) Kunth, An. HCIB: AMN 2012163, JLLL 573, RDC 3122RDC 3967.

Eriochloa aristata Vasey, An. HCIB: MDL 4539.

Heteropogon contortus (L.) P.Beauv. ex Roem. et Schult., Ph. HCIB: AMN 2012-015, JLLL 11472, UC: TSB s/n.

Leptochloa dubia (Kunth) Nees., Ph. HCIB: AMN 2011-168, 
Appendix 1. Continuation

AMN 2011-193, 2011-217, 2011-232, 2011-261, 2011357, UC: TSB s/n, TSB s/n.

Leptochloa fusca (L.) Kunth subsp. fascicularis (Lam.) N.W. Snow., Ph. HCIB: JLLL 487.

Leptochloa panicea (Retz.) Ohwi., Ph. HCIB: JLLL 11493.

Leptochloa panicea (Retz) Ohwi. subsp. brachiata (Steud.) Snow., Ph. HCIB: JLLL 491.

Leptochloa viscida (Scribn.) Beal., Ph. HCIB: JLLL 528, 560, 1261, MDL 4469, RDC 3169.

Monanthochloe littoralis Engelm. [Distichlis I.], Ph. HCIB: AMN 2011-188, 2011-210, 2011-252, 2012-038, JJPN 509, 541, 581, JLLL 551, 1500, MDL 4739, 4830, RDC 3505, 3683, 3689, 3782, SD: RMB 2135, UC: TSB s/n.

Muhlenbergia appressa C.O. Goodd., An. HCIB: JLLL 11488. Muhlenbergia brandegeei C. Reeder, An. HCIB: RDC 3256.

Muhlenbergia microsperma (DC.) Kunth, An. HCIB: JLLL 493, 1354, RDC 3113, 3151.

Panicum hirticaule J. Presl. [P. capillare var. h.], An. HCIB: AMN 2012-168, JLLL 1266, MDL 4541, RDC 3115, 3155, $3182,3969$.

* Pennisetum ciliare (L.) Link [Cenchrus ciliaris], Ph. HCIB: JLLL 502, 1516, 11202, 11249, MDL 4491, 4445b, s/n, RDC 3288, 3344, 3773, 3895, s/n. Zacate buffel.

*Setaria adhaerens (Forssk.) Chiov., An. HCIB: JLLL 482, 1221, RDC 3132.

Spartina foliosa Trin., Hf. HCIB: AMN 2011-189, 2011-211,
JLLL 552, 1495, RDC 3686, SD: JJPN 567, PJM 856, UC: TSB s/n.

Sporobolus contractus Hitchc., An. HCIB: AMN 2012-149, JLLL 1391, HCIB, RDC s/n.

Sporobolus cryptandrus (Torr.) A. Gray, Ph. HCIB: AMN 2012158, JLLL 11397, MDL 4592, SD: PJM 841.

Sporobolus pyramidatus (Lam.) Hitchc., An. HCIB: AMN 2012-171, JLLL 1505, MDL 4424, RDC 3121, 3785, 3907. Sporobolus virginicus (L.) Kunth, Ph. HCIB: AMN 2011-180, 2011-190, 2011-198, 2011-205, 2011-212, 2011-253, JJPN 558, 571, MDL 4592b, SD: MDL 3912, PJM 830, UC: TSB s/n.

Tuctoria fragilis (Swallen) Reeder, An. HCIB: MDL 3854, 4598, SD: JRR 7144.

Urochloa arizonica (Scribn. et Merr.) Morrone et Zuloaga [Brachiaria a.], An. HCIB: MDL 4508.

Urochloa fusca (Sw.) B.F. Hansen et Wunderlin. [Panicum fasciculatum var. fuscum], An. HCIB: AMN 2012-164, MDL 2841, SD: FG 9791.

TYPHACEAE

Typha latifolia L., Hf. HCIB: RDC 3159.

ZOSTERACEAE

Phyllospadix scouleri Hook., Hf. HCIB: JLLL s/n.

Phyllospadix torreyi S. Watson, Hf. HCIB: JLLL 1496, 1535, MDL 4726.

Zostera marina L., Hf. HCIB: RDC s/n. 